\title{
Two new species of the Hypostomus cochliodon group (Siluriformes: Loricariidae) from the rio Paraguay basin, with a redescription of Hypostomus cochliodon Kner, 1854
}

\author{
Luiz F. C. Tencatt ${ }^{1}$, Cláudio H. Zawadzki² and Otávio Froehlich ${ }^{3}$
}

Hypostomus cochliodon group is a monophyletic clade of 20 valid species of Neotropical armored catfishes that is widely distributed throughout South America. Recently, specimens identified as H. cochliodon from the type locality and nearby localities were examined, and found to include representatives of more than one species. A redescription of $H$. cochliodon is provided, with a description of two new species, one from the Bodoquena Plateau and another from several localities of the rio Paraguay basin. A lectotype for $H$. cochliodon is designated herein, since the previous designation is invalid. Hypostomus cochliodon is diagnosed from all other species of the $H$. cochliodon group by having the opercle almost completely covered laterally by thick layer of skin, the absence of buccal papilla, weak to moderately developed keels on the lateral plates of the body and by the color pattern of its body and fins. Hypostomus basilisko, new species, is distinguished from the remaining species of the $H$. cochliodon group by the absence of spots on the body, highly developed keels and spoon-shaped teeth. Hypostomus khimaera, new species, is distinguished from the other species of the H. cochliodon group by having a dark tan stripe along the midline of the flank, black spots on the body and/or fins and teeth with mesial cusp and not spoon-shaped.

O grupo Hypostomus cochliodon é um clado monofilético com 20 espécies válidas de cascudos neotropicais que estão amplamente distribuídos por toda América do Sul. Recentemente, espécimes identificados como $H$. cochliodon da localidadetipo e regiões próximas foram examinados e descobriu-se que se tratavam de representantes de mais de uma espécie. Uma redescrição de $H$. cochliodon é apresentada, com a descrição de duas espécies novas, uma da Serra da Bodoquena e outra de várias localidades da bacia do rio Paraguai. Um lectótipo para $H$. cochliodon é aqui designado, já que a designação anterior é inválida. Hypostomus cochliodon é diagnosticado de todas as outras espécies do grupo H. cochliodon por possuir opérculo quase completamente coberto lateralmente por uma grossa camada de pele, ausência de papila bucal, placas laterais do corpo com quilhas fracas ou moderadamente desenvolvidas e pelo padrão de coloração de seu corpo e nadadeiras. Hypostomus basilisko, espécie nova, é distinguida das demais espécies do grupo $H$. cochliodon pela ausência de pintas no corpo, quilhas muito desenvolvidas e dentes em forma de colher. Hypostomus khimaera, espécie nova, é distinguida das outras espécies do grupo $H$. cochliodon por possuir uma faixa escura ao longo da linha mediana do corpo, pintas pretas no corpo e/ou nadadeiras e dentes com cúspide mesial não em forma de colher.

Key words: Armored catfish, Hypostominae, Neotropical fishes, rio Cuiabá, Taxonomy.

\section{Introduction}

The Hypostomus cochliodon group is a monophyletic clade (Montoya Burgos et al., 2002; Weber \& Montoya Burgos, 2002; Armbruster, 2003, 2004; Armbruster \& de Souza, 2005), of armored catfishes that, together with Panaque Eigenmann \&
Eigenmann, comprises the only species of fishes with a diet consisting predominantly of wood (Schaefer \& Stewart, 1993; Nelson et al., 1999). The H. cochliodon group includes 20 valid nominal species (Hollanda Carvalho et al., 2010) that are widely distributed throughout South America (Armbruster, 2003; Hollanda Carvalho \& Weber, 2004; Armbruster \& de Souza,

\footnotetext{
${ }^{1}$ Universidade Estadual de Maringá, Programa de Pós-Graduação em Ecologia de Ambientes Aquáticos Continentais. Av. Colombo, 5790, 87020-900 Maringá, PR, Brazil. luiztencatt@hotmail.com

${ }^{2}$ Universidade Estadual de Maringá, Departamento de Biologia/ Núcleo de Pesquisas em Limnologia, Ictiologia e Aquicultura (Nupélia). Av. Colombo, 5790, Nupélia G90, 87020-900 Maringá, PR, Brazil. chzawadzki@hotmail.com

${ }^{3}$ Universidade Federal de Mato Grosso do Sul, Laboratório de Zoologia/Centro de Ciências Biológicas e da Saúde. Caixa Postal 549, 79070900 Campo Grande, MS, Brazil. otaviofr@gmail.com
} 
2005). Armbruster (2004) discovered three synapomorphies of the $H$. cochliodon group, the loss of a notch between the metapterygoid and hyomadibula, strongly angled dentaries and spoon-shaped teeth, although the last character is not present in all members of the group (Armbruster, 2003, 2004). Taxonomic studies for this group have been frequent (e.g., Armbruster, 2003; Hollanda Carvalho \& Weber, 2004; Armbruster \& de Souza, 2005; Hollanda Carvalho et al., 2010) but most of them were mainly focused on the Amazonian representatives.

Hypostomus cochliodon Kner was described from the rio Cuiabá basin, based on five syntypes collected by Natterer. Armbruster (2003) reported that Hypostomus cochliodon was found exclusively in the rio Paraguay basin, but Weber (2003) noted that its distribution included the middle rio Paraná basin. More recently, $H$. cochliodon was also reported from the upper rio Paraná basin, due to flooding of the Sete Quedas falls after the construction of the Itaipu reservoir (Zawadzki et al., 2005; Graça \& Pavanelli, 2007).

In the original description, Kner (1854) described the color pattern of Hypostomus cochliodon based on his observations of the syntypes and remarks in Natterer's field notes. The author noted a concentration of small black spots on the dorsal portion of the head, which are scarce along the trunk. Kner (1854) also mentioned the presence of black spots on the fins as well as the bicolored pattern of the fins, which present their proximal basis at the same color as the body and distal tips darker. Armbruster (2003) performed a comprehensive taxonomic review of the $H$. cochliodon group, providing redescriptions of the previously described species and describing four new species. In the same paper, Armbruster stated that H. cochliodon possesses color pattern of the body generally entirely dark brown, with a dark tan stripe in the midline of the flank; stripe sometimes crossed by dark saddles or with dark spots anteriorly. Hollanda Carvalho \& Weber (2004) raised some issues in the redescription of $H$. cochliodon made by Armbruster (2003). Initially, there was a contradiction in color patterns described by Armbruster (2003) versus those mentioned in the original description by Kner (1854), mainly by the presence of a dark tan stripe in the midline of the flank in H. cochliodon, reported by Armbruster (2003) but which was not mentioned in Kner's description.

Other point in Armbruster's (2003) paper commented by Hollanda Carvalho \& Weber (2004) were the diagnostic characters, which have very large variation, such as the number of teeth ranging from 6 to 27. In Kner's (1854) description, the number of teeth ranged from seven to eight. Hollanda Carvalho \& Weber (2004) suggested the possibility that in the redescription of Hypostomus cochliodon made by Armbruster (2003) the author had not examined what would be the true $H$. cochliodon, with exception of two syntypes (NMW 46277 and NMW 44101). In addition, the authors commented that the designation of the $H$. cochliodon lectotype by Armbruster (2003) was not valid since it is not in accordance with the Declaration 44, amendment of Article 74.7.3 of the International Commission on Zoological Nomenclature. Hollanda Carvalho \& Weber (2004) also highlighted the need of further studies encompassing several additional populations of $H$. cochliodon from the rio Paraguay basin. Armbruster (2003) and Hollanda Carvalho \& Weber (2004) suggested that $H$. cochliodon from the rio Paraguay basin is likely a complex of species.

From the examination of several recent collected specimens from the rios Paraná and Paraguay basins it was possible to confirm that more than one species of the Hypostomus cochliodon group coexist not only in the rio Cuiabá (the type locality of $H$. cochliodon), but also in other regions of the rio Paraguay basin. From the analysis of fish from several localities within the rio Paraguay basin, specimens having a dark tan stripe mentioned by Armbruster (2003) were revealed to be a new species, which is described herein.

Additionally, specimens from the Bodoquena Plateau, Mato Grosso do Sul State, Brazil, revealed another undescribed species of the Hypostomus cochliodon group, whose description is also presented herein. The redescription of Hypostomus cochliodon with the designation of a lectotype is also provided.

\section{Material and Methods}

Measurements were made with digital calipers to the nearest $0.1 \mathrm{~mm}$. Methodology and terminology for measurements follow Boeseman (1968) with modifications of Weber (1985) and Zawadzki et al. (2008). Plate counts and nomenclature follow Schaefer (1997), with the modifications of Oyakawa et al. (2005). Standard length (SL) is expressed in millimeters and all other measurements are expressed as percentages of standard length or head length (HL). Vertebral and rib counts were taken from cleared-and-stained (c\&s) specimens prepared according to Taylor \& Van Dyke (1985). The vertebral complex of the Weberian apparatus and the compound caudal centra are each counted as a single element. Syntypes of Hypostomus cochliodon, NMW 46277 and NMW 59395, were examined through high definition photographs. In the species descriptions numbers indicated by an asterisk refer to counts of primary types. Institutional abbreviations are: AMNH, American Museum of Natural History, New York; ANSP, Academy of Natural Sciences of Drexel University, Philadelphia; BMNH, The Natural History Museum, London; CPUFMT, Coleção de Peixes da Universidade Federal do Mato Grosso, Cuiabá; INPA, Instituto Nacional de Pesquisas da Amazônia, Manaus; LBP, Laboratório de Biologia e Genética de Peixes, Universidade Estadual Paulista "Júlio de Mesquita Filho", Botucatu; MCP, Museu de Ciências e Tecnologia da Pontifícia Universidade Católica, Porto Alegre; MCZ, Museum of Comparative Zoology, Harvard University, Cambridge; MHNG, Museum d'histoire naturelle de la Ville de Genève, Geneva; MNHN, Museum National d'histoire naturelle, Paris; MNRJ, Museu Nacional, Rio de Janeiro; MZUEL, Museu de Zoologia da Universidade Estadual de Londrina, Londrina; MZUSP, Museu de Zoologia, Universidade de São Paulo, São Paulo; NUP, Coleção Ictiológica do Núcleo de Pesquisas em Limnologia, Ictiologia e Aquicultura da Universidade Estadual de Maringá, Maringá; UMSS, Universidad Mayor de San Simón, Facultad de Ciencias y Tecnologia, Centro de 


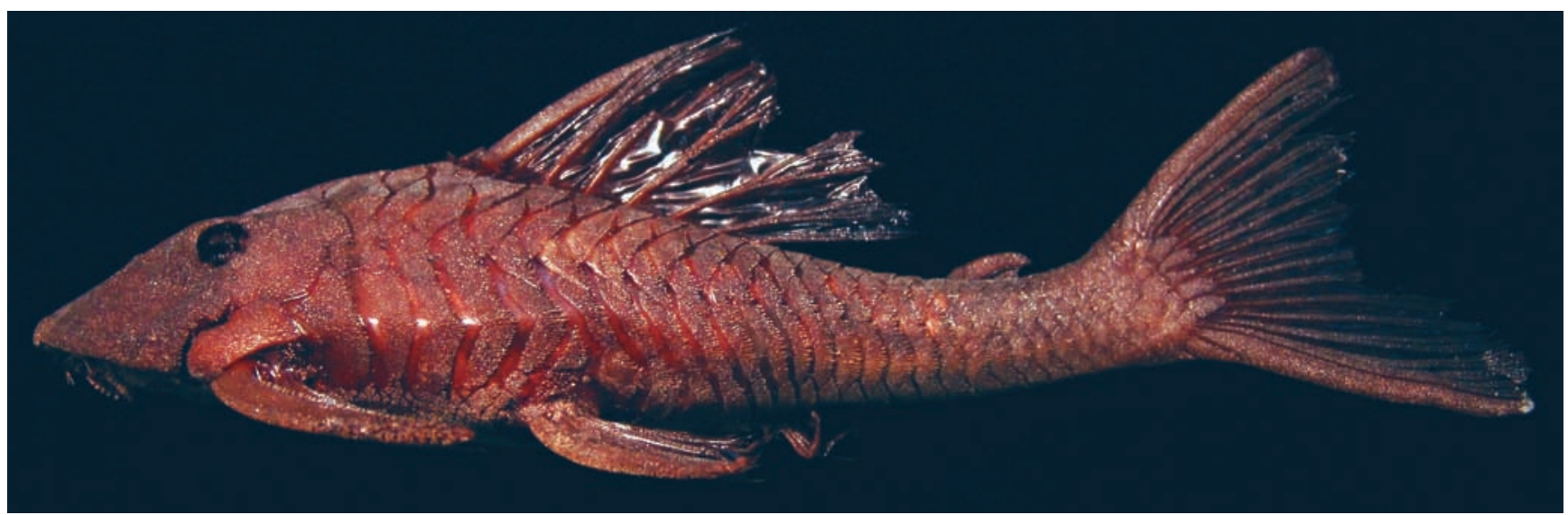

Fig. 1. Hypostomus cochliodon, lectotype, NMW 44101, 182.5 mm SL, rio Cuiabá, in lateral view.

Biodiversidad, Zoología, Laboratorio de Ictiología, Cochabamba; ZMA, Zoologisches Museum, Universiteit van Amsterdam, Amsterdam; ZUFMS-PIS, Coleção Zoológica de referência da Universidade Federal do Mato Grosso do Sul, Campo Grande.

\section{Results}

\section{Hypostomus cochliodon Kner, 1854}

Figs. 1, 2, 3a, 4a, 5a, 6a, 7, 8

Hypostomus cochliodon Kner, 1854: 265, Pl. 2 fig. 1, "Rio Cujaba” (= rio Cuiabá). Lectotype NMW 44101, by present designation.

Cochliodon hypostomus Kner, 1854: 265.

Loricaria melanoptera Kner, 1854: 265.

Diagnosis. Hypostomus cochliodon is distinguished from all other species of Hypostomus, except those belonging to the $H$. cochliodon group, by having the following unique combination of features: notch between metapterygoid and hyomandibula absent (vs. notch present) and strongly angled dentaries, less than $80^{\circ}$ (vs. shallow angle between dentaries, generally more than $80^{\circ}$ ). Hypostomus cochliodon can be distinguished from the other species of the $H$. cochliodon group, except from $H$. dardanelos Zawadzki \& Hollanda Carvalho, H. ericae Hollanda Carvalho \& Weber, H. ericius Armbruster, H. oculeus (Fowler), H. paucipunctatus Hollanda Carvalho \& Weber, H. pyrineusi (Miranda Ribeiro), H. taphorni (Lilyestrom) and $H$. waiampi Hollanda Carvalho \& Weber by having the opercle almost completely covered by thick layer of skin and exposed region not easily visible (see Fig. 3a) (vs. externalized opercle and exposed region easily visible, Fig. $3 \mathrm{~b}, \mathrm{c})$. It can be distinguished from $H$. ericae, $H$. paucipunctatus, and $H$. waiampi by the absence of buccal papilla (vs. presence); from $H$. dardanelos, $H$. ericius, and $H$. oculeus by the presence of weak to moderately developed keels on lateral plates (vs. strongly developed); from $H$. pyrineusi by the presence of small black spots closely-set on head and larger, widely spaced spots on trunk, with caudal peduncle generally without spots (vs. uniform spot pattern with head, trunk and fins densely covered by closely-set black spots); from $H$. taphorni by having both caudal-fin lobes evenly colored (vs. bicolored caudal fin with ventral lobe darker). Hypostomus cochliodon is further distinguished from H. hemicochliodon Armbruster, H. kopeyaka Hollanda Carvalho, Lima \& Zawadzki, H. khimaera, H. soniae Hollanda Carvalho \& Weber, H. sculpodon Armbruster, and H. weberi Hollanda Carvalho, Lima \& Zawadzki by the presence of bicuspid teeth with a large spoon-shaped mesial cusp and inconspicuous lateral cusp that is generally fused to mesial cusp (vs. bicuspid teeth with mesial cusp conspicuously large and round but not spoon-shaped and with distinct lateral cusp). It further differs from $H$. basilisko and $H$. khimaera by the absence of a longitudinal dark stripe along midline of flank (vs. presence); from $H$. levis (Pearson) by the presence of an adipose fin ( $v s$. absence).

Description. Morphometric data in Table 1. Overall view of body in Fig. 2, juvenile in Fig. 4a. Head broad, moderately deep and slightly compressed. Snout and anterior profile of head pointed in dorsal view. Eye moderate in size, laterally positioned. Dorsal margin of orbit not raised. Greatest body width at cleithrum, decreasing to caudal peduncle. Dorsal profile of head straight from snout tip to vertical through interorbital region, and forming angle of $45^{\circ}$ with ventral region of head; convex from that point to dorsal-fin origin; sloped downward to first dorsal caudal-fin procurrent rays, then elevating again to caudal-fin insertion. Ventral profile almost straight from snout tip to insertion of pelvic-fin unbranched ray; slightly straight from pelvic-fin insertion to first ventral caudal-fin procurrent ray, then descending to caudal-fin insertion. Caudal peduncle laterally compressed, ellipsoid on its whole extension. Mesethmoid region rough. Supraoccipital bone with highlydeveloped median ridge; with short posterior process bordered by single plate. Moderate ridge originating lateral to nares, passing through supraorbital, and extending very slightly through superior portion of compound pterotic. Opercle small, almost not exposed and generally not supporting odontodes (Fig. 3a). Oral disk round, moderate in size, lower lip not reaching 


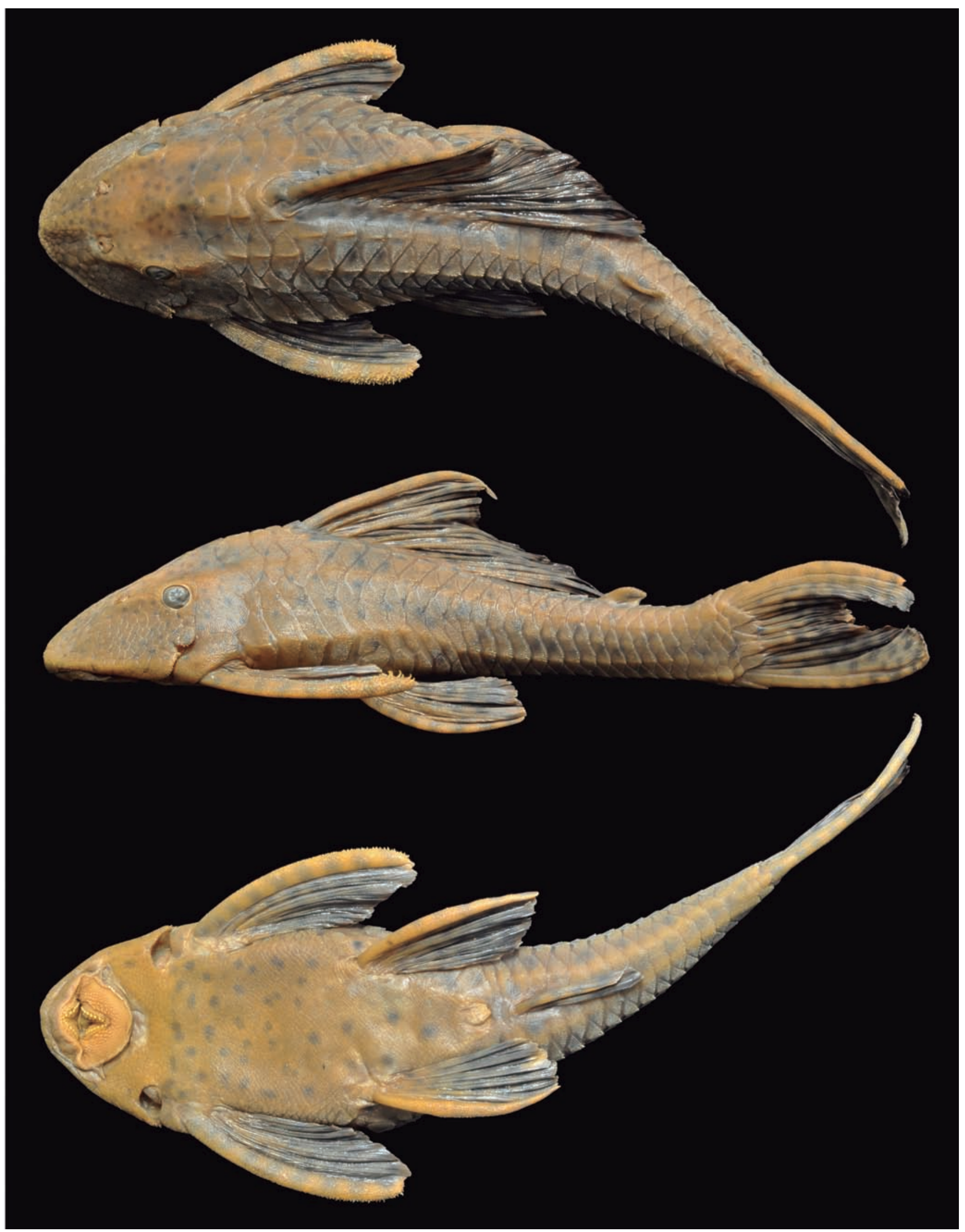

Fig. 2. Hypostomus cochliodon, NUP 10807, 208.0 mm SL; dorsal (top), lateral (middle), and ventral (bottom) views. 


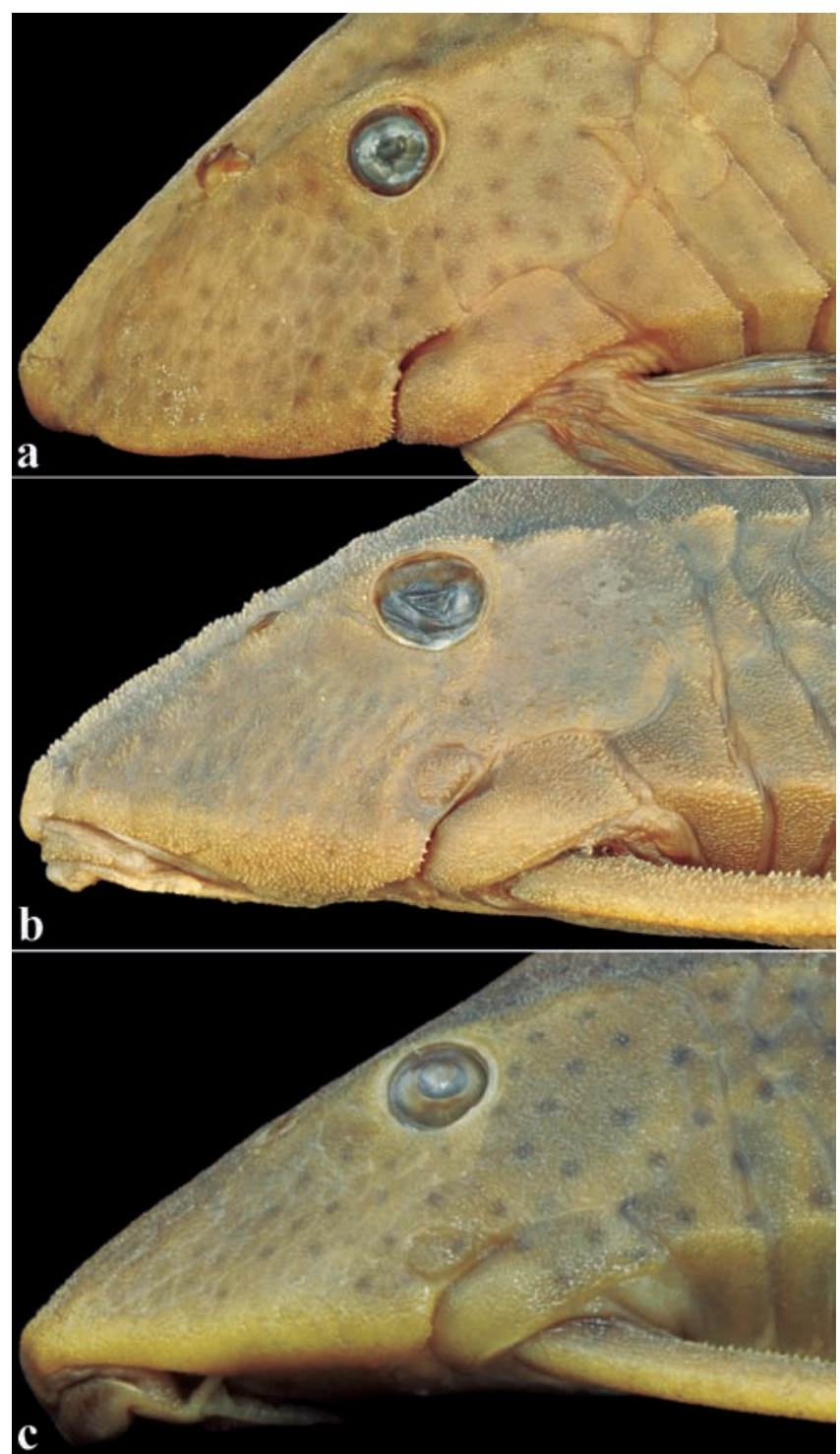

Fig. 3. Opercle morphology of (a) Hypostomus cochliodon, NUP 10809, $215.8 \mathrm{~mm}$ SL, showing indistinct opercle without odontodes; (b) Hypostomus basilisko, holotype, MZUSP 111110, $182.5 \mathrm{~mm}$ SL and (c) Hypostomus khimaera, holotype, MZUSP 111129, $139.1 \mathrm{~mm}$ SL, showing layer of skin surrounding opercle that supports odontodes.

transversal through gill openings (Fig. 5a); ventral surface covered with numerous small papillae decreasing in size posteriorly. Maxillary barbel slightly smaller than eye diameter. Odontodes present on anterior surface of upper lip, just below snout. Buccal papilla (sensu Armbruster, 2003) absent. Dentaries acutely angled, averaging less than $80^{\circ}$ between left and right dentary rami. Seven to 9 (mode 7, lectotype 8 ) teeth in premaxilla, 7 to 9 (mode 8, lectotype 7) in dentary. Teeth spoon-shaped, bicuspid with lateral cusp very reduced or fused to mesial cusp (see Armbruster, 2003, fig. 1c). Juveniles, up to $80 \mathrm{~mm}$ SL, with villiform bicuspid teeth, similar to those in most species of Hypostomus (see Armbruster, 2003, fig. 1c).

Body dorsally covered with five rows of dermal plates with weak-developed odontodes, except on base of dorsal fin and small naked area on snout tip. Predorsal region with slight median keel. These keels slightly diverge posteriorly (Fig. 6a). Dorsal and mid-dorsal series of plates with very slight keels. Median series bearing lateral line and without keels. Mid-ventral series angled to fifth or to sixth plate; slightly bent ventrally on caudal peduncle region. Ventral series without keel. Ventral surface of head covered with platelets, with exception of region beneath lower lip. Abdomen covered with minute platelets in specimens larger than $80 \mathrm{~mm}$ SL, with exception of very small areas around pectoral- and pelvic-fin insertions and at urogenital opening. Preanal plate present. Median series of plates with 27-29 (mode 28*), three predorsal plates, plates between dorsal and adipose fins $7 *-9$ (mode 8 ), plates between adipose and caudal fins $7 *-9$ (mode 8); plates below dorsal-fin base 7-8* (mode 7).

Dorsal fin II,7, its origin at vertical through midpoint between pectoral and pelvic fins, or slightly posterior to that point. Dorsal-fin distal margin straight; dorsal-fin ray tips not reaching adipose spine. Adipose-fin spine compressed and curved inward. Pectoral fin I,6, its distal border straight. Pectoral-fin spine slightly curved inward, covered with moderately developed odontodes, more developed on its distal portion and in larger specimens. Tip of adpressed pectoral fin reaching to basal one-third of adpressed pelvic-fin spine. Pelvic fin i,5, its distal border convex; its adpressed unbranched ray surpassing anal-fin origin. Anal fin i,4, its tip reaching fifth to sixth plate after its origin. Rays of anal fin progressively increasing in size posteriorly, third branched ray generally longest. Caudal fin i,14,i, its margin falcate, with both lobes similar in length.

Color in alcohol. Ground color of head and trunk grayish brown; ventral surface of body yellowish brown. Spots at least in some part of body and fins in all specimens. Presence of many small dark spots on head, mainly on top of head and compound pterotic; spots on trunk sparce, more faded and generally larger than those in head and widely spaced (Fig. 7a) in some specimens from rio Paraguay basin. Spots closely spaced on ventral surface of body in some specimens from rio Paraguay basin. Caudal peduncle generally without spots. All fins with spots on spines, unbranched and branched rays and membrane. Proximal region of fins with same color to ventral surface of body, becoming dark brown towards distal portions (Fig. 7b) in some larger specimens from both rios Paraguay and Paraná basins; uniform ground color on fins in some specimens. Larger and more widely spaced spots on dorsal portion of body and head; spots generally more closely spaced on ventral surface of body in some specimens from upper rio Paraná basin.

Color in life. Color pattern of live specimens is very similar to that of preserved ones (Fig. 8).

Sexual dimorphism. No sexual dimorphism was observed.

Distribution. Hypostomus cochliodon is known from the rio 
Paraguay basin, as well as from the middle and upper rio Paraná basins (Fig. 9). In the upper rio Paraná basin, it is known from downstream of the Porto Primavera reservoir, which is the first reservoir upstream of the Itaipu reservoir, suggesting that the species colonized this region after the flooding of the Sete Quedas falls by the construction of the Itaipu reservoir in 1982. No records of the species in the upper rio Paraná are known before this period.

Material examined. 166 specimens. Brazil. Mato Grosso. MNRJ 28048, 2, 105.8-145.7 mm SL; NUP 3602, 1, 150.5 mm SL; NUP 10807, 1, 208.0 mm SL; NUP 12003, 1, 186.9 mm SL; NUP 12671, 1, $193.1 \mathrm{~mm}$ SL; and NUP 13421, 1, $154.4 \mathrm{~mm}$ SL, rio Manso. MZUSP 26803, 4, 147.1-183.2 mm SL, rio Coxipó. MZUSP 36728, 1, 231.6 mm SL, rio Piquiri. MZUSP 38185, 1, 191.7 mm SL, mouth of the rio Varadouro. MZUSP 56757, 1, 173.0 mm SL, rio Cuiabá. NMW 44101, 1, 182.5 mm SL, “Rio Cujaba” (= rio Cuiabá), lectotype of Hypostomus cochliodon Kner, by present designation. NMW 46277, 1, $153.0 \mathrm{~mm} \mathrm{SL}$; and NMW 59395, 1, $210.0 \mathrm{~mm} \mathrm{SL}$, paralectotypes of Hypostomus cochliodon Kner. NUP 903, 7, 20.5$185.1 \mathrm{~mm}$ SL; NUP 9619, 28, 20.0-71.8 mm SL; NUP 12001, 1, 202.8 mm SL; NUP 12498, 6, 76.2-88.3 mm SL; and NUP 13271, 1, 221.6 mm SL, Manso Reservoir. NUP 3257, 1, 203.9 mm SL, rio Casca. NUP 11931, 2, 53.6-53.8 mm SL; and NUP 13833, 1 c\&s, 69.2 mm SL, córrego Descalvado. NUP 11936, 6, 46.6-53.7 mm SL, córrego Cambará. NUP 11956, 5, 38.6-92.8 mm SL, córrego Palmeira. NUP 12000, 2, 155.8-174.1 mm SL; NUP 12002, 1, 219.5 mm SL; NUP 12017, 1, 157.8 mm SL; NUP 12071, 2, 145.5-151.3 mm SL;

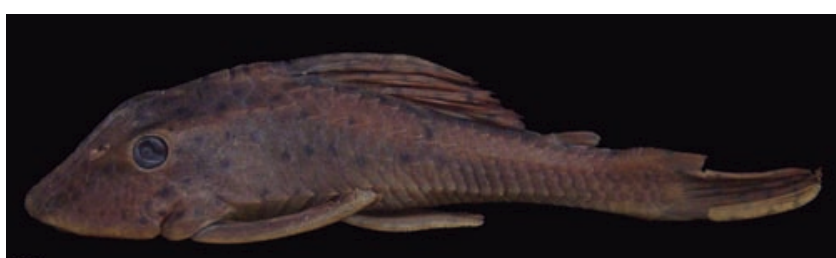

a

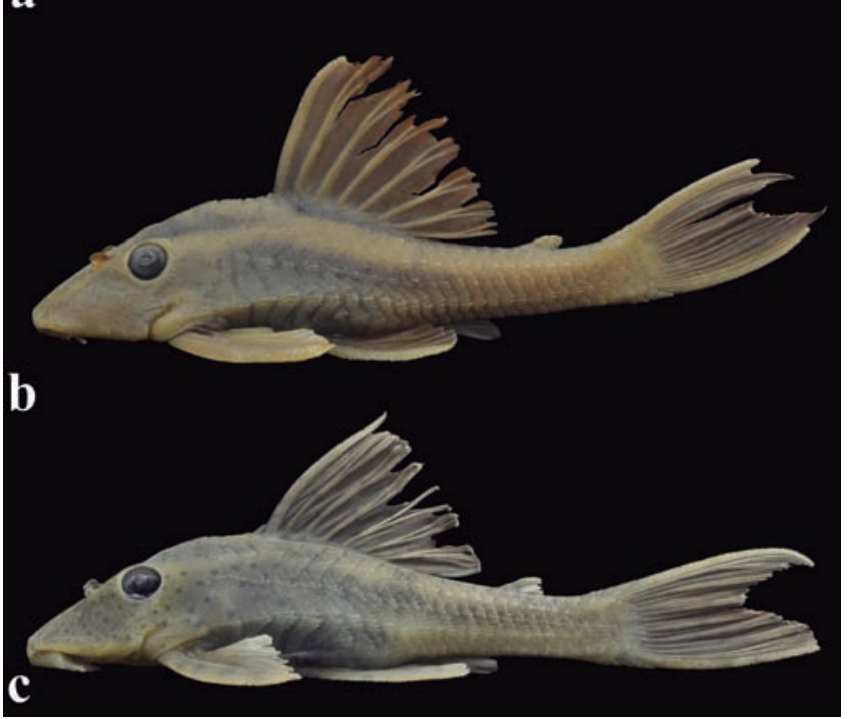

Fig. 4. Lateral view of juvenile in (a) Hypostomus cochliodon, NUP 11956, 92.8 mm SL, (b) Hypostomus basilisko, paratype, ZUFMS-PIS 3083, 64.2 mm SL and (c) Hypostomus khimaera, NUP 13494, $68.8 \mathrm{~mm}$ SL. and NUP 12670, 1, 155.5 mm SL, rio Cuiabá. NUP 12069, 2, 125.5151.5 mm SL; and NUP 13479, 5, 49.0-160.8 mm SL, córrego Cancela. NUP 13488, 1, 123.0 mm SL, rio Jangada. Mato Grosso do Sul. FMNH 108106, 1, 146.0 mm SL; and FMNH 108113, 8, 31.0-65.6 mm SL, rio Paraguay. FMNH 108116, 1, 92.0 mm SL, rio Apa. FMNH 108588, 4, 35.0-51.0 mm SL, córrego do Engano. NUP 9341, 6, 37.2-60.7 mm SL, córrego Feio. NUP 9822, 6, 26.8-143.0 mm SL; and NUP 10806, 7, 41.2-128.2 mm SL, córrego da Onça. NUP 10809, 2, 165.0-215.8 mm SL; NUP 13282, 1, $195.2 \mathrm{~mm} \mathrm{SL;} \mathrm{and} \mathrm{NUP}$ 13283, 3, 184.4-252.1 mm SL, rio Ivinheima. NUP 12074, 2, 166.3186.5 mm SL, rio Taquari. NUP 12145, 1, 157.8 mm SL, canal Ipoitã. NUP 12146, 1, 157.0 mm SL; NUP 12768, 1, 241.1 mm SL; and NUP 13279, 3, 170.7-190.6 mm SL, canal Curutuba. NUP 13495, 1, $62.0 \mathrm{~mm}$ SL, stream tributary to rio Aquidauana. NUP 13496, 10, 35.2-89.8 mm SL, ribeirão Salobra. ZUFMS-PIS 3087, 2, 205.2207.8 mm SL, rio Vacaria. ZUFMS-PIS 3093, 1, 210.0 mm SL; and ZUFMS-PIS 3094, 1, 136.2 mm SL, córrego Salobrinha. Paraná State. NUP 2556, 8, 154.1-238.4 mm SL; and NUP 4074, 1, 127.6 mm SL, Itaipu Reservoir. NUP 2571, 1, 147.8 mm SL; and NUP 13284, 1, 235.9 mm SL, rio Paraná. NUP 4506, 1, 135.7 mm SL, arroio Guaçu. NUP 13541, 2, 115.0-125.0 mm SL, rio Iguaçu. Unknown locality. CAS 102213, 1, 83.0 mm SL, locality listed only as Brazil. Paraguay. Concepción. MCP 10978, 1, 191.1 mm SL, arroyo Tagatija-Guazu.

\section{Hypostomus basilisko, new species}

Figs. 3b, 4b, 5b, 6b, 10, 11, 12

Holotype. MZUSP 111110, 182.5 mm SL, Brazil, Mato Grosso do Sul State, Bodoquena, córrego Salobrinha, rio Paraguay basin, 2040’33"S 5646’34"W, Mar 2007, O. Froehlich.

Paratypes. All from Brazil, Mato Grosso do Sul, Bodoquena, rio Paraguay basin (268 specimens). CPUFMT 1448, 1, 171.2 mm SL, rio Salobra, 2046’49"S 56²4’31"W, Dec 2005, O. Froehlich. FMNH 108584, 3, 142.0-184.0 mm SL, córrego Salobrinha, 2040’43"S 5646’52"W, 7 Sep 1998, N. Menezes, J. Sabino, A. M. Zanata, M. Toledo-Piza \& R. Lourival. INPA 37743, 4, 151.5-160.5 mm SL, córrego Salobrinha, 2040’33"S 5646’34"W, Mar 2007, O. Froehlich. MCP 47140, 2, 166.8-173.2 mm SL, rio Salobra, 2046’49"S 56²4’31"W, Dec 2005, O. Froehlich. MNRJ 40184, 4, 143.5-161.0 mm SL, córrego Salobrinha, 2040’33"S 5646’34"W, Mar 2007, O. Froehlich. MZUSP 59986, 11, 31.1-46.5 mm SL, córrego Salobrinha, 3-4 Mar 2002, N. Menezes, J. Sabino, A. Zanata \& M. Toledo-Piza. MZUSP 111.128, 5, 111.5-163.0 mm SL, córrego Salobrinha, 2040’12"S 5646’12"W, Mar 2007, O. Froehlich. NUP 5076, 3, 144.5-183.8 mm SL, rio Salobra, 20²9’44"S 5651’48"W, 27 Dec 2006, A. G. Bifi. NUP 13832, 1 c\&s, 53.9 mm SL, rio Salobra, 20²9’44"S 5651’48"W, 27 Dec 2006, A. G. Bifi. NUP 14503, 1, 171.9 mm SL, rio Salobra, 2046’49"S 5644’31"W, 3 Sep 2005, O. Froehlich. NUP 14504, 1, 154.6 mm SL, córrego Salobrinha, 2040’12"S 56²6’12"W, 31 Jul 2006, O. Froehlich. NUP 14505, 7, 37.5-165.9 mm SL, córrego Salobrinha, 2040’12"S 5646’12"W, Mar 2007, O. Froehlich. ZUFMS-PIS 1039, 1, 39.0 mm SL, rio Salobra, 13 Oct 2001, O. Froehlich. ZUFMS-PIS 1294, 1, 115.0 mm SL, córrego Salobrinha, 17 May 2001, O. Froehlich. ZUFMS-PIS 1460, 3, 42.553.0 mm SL, córrego Salobrinha, 9 Sep 2001, E. Amorim, J. Sedenho, M. R. Carvalho \& L. P. C. Lopes. ZUFMS-PIS 1531, 23, 35.5-65.0 mm SL, córrego Salobrinha, 18 Sep 2000, O. Froehlich. ZUFMS-PIS 1641, 16, 31.0-68.5 mm SL, córrego Salobrinha, 20 May 2000, O. Froehlich. ZUFMS-PIS 1686, 1, 168.7 mm SL, córrego Salobrinha, 2040’12"S 5646’12"W, 18 Sep 2000, O. Froehlich. ZUFMS-PIS 
2491, 13, 145.0-197.8 mm SL, rio Salobra, 2046’49"S 5644’31"W, 18 Dec 2005, O. Froehlich. ZUFMS- PIS 3082, 32, 20.3-113.5 mm SL, córrego Salobrinha, 2040’12"S 5646’12"W, Mar 2007, O. Froehlich. ZUFMS-PIS 3083, 14, 25.8-156.6 mm SL, córrego Salobrinha, 2040’33"S 5646’34"W, Mar 2007, O. Froehlich. ZUFMS-PIS 3084, 24, 34.0-122.6 mm SL, córrego Salobrinha, 2040’12"S 5646’12"W, 31 Jul 2006, O. Froehlich. ZUFMS-PIS 3085, 2, 133.7-143.8 mm SL, córrego Salobrinha, 2041’01"S 56²7’07"W, 23 Mar 2007, O. Froehlich. ZUFMS-PIS 2490, 6, 136.7163.1 mm SL, córrego Salobrinha, 2041’09"S 5647’00"W, 15 Dec 2005, O. Froehlich. ZUFMS-PIS 3086, 4, 148.1-170.3 mm SL, córrego Salobrinha, 2040’35"S 5646’12"W, 16 Jul 2011, O. Froehlich. ZUFMS-PIS 3088, 4, 130.6-175.4 mm SL, córrego Salobrinha, 2040’59"S 5647'12"W, 26 Jul 2006, O. Froehlich. ZUFMS-PIS 3089, 17, 74.7-171.9 mm SL, córrego Salobrinha, 2041’09"S 5646’53"W, 29 Jul 2006, O. Froehlich. ZUFMS-PIS 3090, 1, 163.7 mm SL, rio Salobra, 2046’49"S 5644’31"W, 10 Aug 2008, O. Froehlich. ZUFMS-PIS 3091, 26, 36.1-165.3 mm SL, córrego Salobrinha, 2040’59"S 5647’12"W, Jul 2006, O. Froehlich. ZUFMSPIS 3092, 38, 37.1-165.0 mm SL, córrego Salobrinha, 2040’23"S 56²6’25"W, Mar 2007, O. Froehlich.

Diagnosis. Hypostomus basilisko is distinguished from all other Hypostomus species, except those belonging to the $H$. cochliodon group, by having the following unique combination of features: notch between metapterygoid and hyomandibula absent (vs. notch present) and strongly angled dentaries, less than $80^{\circ}$ (vs. shallow angle between dentaries, generally more than $80^{\circ}$ ). It is distinguished from the other species of $H$. cochliodon group, except $H$. pagei Armbruster and $H$. soniae, by the absence of spots on body and fins (vs. spots present). Hypostomus basilisko can be distinguished from $H$. pagei by having highly developed keels on lateral series of plates (vs. keels weak, almost absent); from $H$. soniae for having teeth with a large spoon-shaped mesial cusp and a lateral cusp, if present, almost imperceptible (vs. teeth with mesial cusp conspicuously enlarged and rounded but not spoon shaped; distinct lateral cusp) and massive odontodes covering the dorsal region of head and trunk, forming well-developed keels (vs. less developed odontodes on head and trunk, keels absent or weakly-developed). It also differs from $H$. soniae by having many well-developed papilla on the internal surface of anterior and posterior jaws (vs. few papillae on the internal surface of anterior and posterior jaws). The new species can be additionally distinguished from $H$. cochliodon and $H$. khimaera by the lower number of vertebrae (27 vs. 29 and 28, respectively); from $H$. hondae (Regan) and $H$. plecostomoides (Eigenmann) by the absence of platelets in the skin around dorsal-fin base (vs. presence of platelets in the skin around dorsal-fin base); from $H$. levis by the presence of an adipose fin (vs. absence); from $H$. taphorni by having both caudal-fin lobes evenly colored (vs. bicolored caudal fin with ventral lobe darker).

Description. Morphometric data in Table 1. Overall view of body in Fig. 10, juvenile in Fig. 4b. Head broad, deep and slightly compressed. Snout and anterior profile of head pointed to slightly round in dorsal view. Eye large, laterally positioned. Dorsal margin of orbit raised. Greatest body width at cleithrum, decreasing to caudal peduncle. Dorsal profile of head straight from snout tip to vertical through interorbital region, and forming $45^{\circ}$ with ventral region of head; convex from that point to dorsal-fin origin; sloped downward to first dorsal caudal-fin

Tabela 1. Morphometric data of Hypostomus basilisko, H. cochliodon and $H$. khimaera. S.D.= standard deviation and $n=$ number of measured specimens.

\begin{tabular}{|c|c|c|c|c|c|c|c|c|c|c|c|c|}
\hline & \multicolumn{4}{|c|}{ H. basilisko } & \multicolumn{4}{|c|}{ H. cochliodon } & \multicolumn{4}{|c|}{ H. khimaera } \\
\hline & $\mathrm{N}$ & Holotype & Range & Mean \pm SD & $\mathrm{N}$ & Lectotype & Range & Mean \pm SD & $\mathrm{N}$ & Holotype & Range & Mean \pm SD \\
\hline \multirow[t]{2}{*}{ Standard length (mm) } & 20 & 182.5 & $113.0-184.1$ & $154.1 \pm 18.2$ & 43 & 176.2 & $67.7-240.6$ & $164.6 \pm 37.2$ & 20 & 139.1 & $102.9-164.0$ & $129.7 \pm 14.6$ \\
\hline & \multicolumn{12}{|c|}{ Percents in standard length } \\
\hline Predorsal length & 20 & 40.1 & 38.1-41.5 & $39.8 \pm 1.3$ & 43 & 38.0 & 39.6-42.5 & $39.9 \pm 1.6$ & 20 & 39.4 & 38.1-41.7 & $39.4 \pm 1.0$ \\
\hline Head length & 20 & 32.2 & 30.4-32.9 & $32.2 \pm 1.2$ & 43 & 30.5 & 28.6-35.5 & $31.7 \pm 1.4$ & 20 & 31.7 & $30.2-34.0$ & $31.7 \pm 1.0$ \\
\hline Interdorsal distance & 20 & 16.2 & $17.2-19.2$ & $17.9 \pm 0.9$ & 43 & 17.2 & 15.6-21.9 & $18.0 \pm 1.6$ & 20 & 20.5 & 14.9-21.5 & $18.5 \pm 1.5$ \\
\hline Thoracic width & 20 & 22.7 & $22.6-24.2$ & $23.4 \pm 0.7$ & 43 & 25.0 & $20.8-26.1$ & $23.3 \pm 1.2$ & 20 & 23.1 & $21.5-24.8$ & $23.0 \pm 0.9$ \\
\hline Abdominal width & 20 & 22.2 & $20.7-22.6$ & $21.5 \pm 0.8$ & 43 & 20.4 & 19.6-23.0 & $21.7 \pm 0.8$ & 20 & 22.5 & $20.4-23.2$ & $21.8 \pm 0.8$ \\
\hline Caudal peduncle length & 20 & 32.3 & 33.9-34.9 & $34.4 \pm 0.5$ & 43 & 33.8 & $29.0-38.8$ & $33.7 \pm 1.7$ & 20 & 33.8 & $30.9-36.3$ & $33.7 \pm 1.3$ \\
\hline Caudal peduncle depth & 20 & 10.2 & $10.8-11.1$ & $11.0 \pm 0.1$ & 43 & 9.4 & 8.8-11.1 & $9.9 \pm 0.6$ & 20 & 9.8 & $9.5-11.2$ & $10.5 \pm 0.5$ \\
\hline Dorsal-fin spine length & 20 & 32.2 & 31.4-36.7 & $33.6 \pm 2.3$ & 41 & - & $16.1-61.8$ & $32.2 \pm 9.8$ & 20 & 30.4 & $26.0-32.0$ & $29.2 \pm 1.5$ \\
\hline Dorsal-fin base length & 20 & 25.6 & $24.1-26.8$ & $25.3 \pm 0.8$ & 43 & 25.1 & $21.5-30.5$ & $26.6 \pm 1.6$ & 20 & 25.3 & $24.6-28.4$ & $26.0 \pm 1.1$ \\
\hline Pectoral-fin spine length & 20 & 29.0 & 29.0-31.2 & $30.3 \pm 1.0$ & 43 & 28.9 & $27.0-34.7$ & $30.7 \pm 1.5$ & 20 & 30.6 & $25.3-30.7$ & $28.8 \pm 1.4$ \\
\hline Pelvic-fin spine length & 20 & 22.9 & 24.3-25.7 & $24.8 \pm 0.6$ & 43 & 23.3 & $21.5-27.5$ & $25.2 \pm 1.2$ & 20 & 25.5 & $22.3-26.3$ & $25.0 \pm 1.1$ \\
\hline Upper caudal-fin ray length & 20 & 30.9 & 28.8-33.2 & $31 \cdot 0 \pm 3 \cdot 1$ & 41 & - & $12.9-48 \cdot 3$ & $28 \cdot 6 \pm 8 \cdot 6$ & 20 & $27 \cdot 4$ & $22.9-33 \cdot 9$ & $28 \cdot 6 \pm 2 \cdot 5$ \\
\hline Lower caudal-fin ray length & 20 & 28.7 & $30.6-34.1$ & $32.3 \pm 1.8$ & 42 & - & $21.6-67.4$ & $32.7 \pm 8.1$ & 20 & 28.3 & $22.5-36.7$ & $29.8 \pm 3.2$ \\
\hline Adipose-fin spine length & 19 & 7.5 & $5.0-7.5$ & $6.6 \pm 0.7$ & 43 & 6.2 & 3.2-7.3 & $6.0 \pm 0.7$ & 20 & 6.4 & 5.4-7.9 & $6.7 \pm 0.7$ \\
\hline \multirow[t]{2}{*}{ Cleithral width } & 20 & 31.8 & $31.1-32.0$ & $31.6 \pm 0.4$ & 43 & 26.7 & $27.8-32.4$ & $29.5 \pm 1.1$ & 20 & 31.3 & 29.6-33.7 & $31.6 \pm 1.1$ \\
\hline & \multicolumn{12}{|c|}{ Percents in head length } \\
\hline Head depth & 20 & 70.6 & $69.0-72.7$ & $69.0 \pm 3.3$ & 43 & 67.9 & $60.8-73.5$ & $67.9 \pm 2.6$ & 20 & 70.5 & $65.8-73.4$ & $69.1 \pm 2.1$ \\
\hline Snout length & 20 & 60.6 & 63.1-68.4 & $65.0 \pm 2.8$ & 43 & 65.5 & 61.9-65.5 & $65.5 \pm 1.9$ & 20 & 65.0 & $60.6-69.4$ & $64.9 \pm 2.6$ \\
\hline Interorbital width & 20 & 47.8 & $47.4-52.2$ & $49.5 \pm 2.3$ & 43 & 51.5 & $46.7-56.5$ & $51.5 \pm 2.0$ & 20 & 45.6 & $41.1-50.7$ & $46.7 \pm 2.4$ \\
\hline Orbital diameter & 20 & 16.9 & $16.2-17.9$ & $17.0 \pm 0.7$ & 43 & 15.3 & $11.5-19.0$ & $15.3 \pm 1.4$ & 20 & 16.6 & $15.4-20.3$ & $17.9 \pm 1.5$ \\
\hline Lower lip width & 20 & 45.5 & $41.1-47.6$ & $43.6 \pm 1.8$ & 43 & 40.3 & $31.8-45.5$ & $40.3 \pm 2.9$ & 20 & 38.7 & $35.2-51.4$ & $43.1 \pm 4.9$ \\
\hline Lower lip length & 20 & 13.2 & $9.0-14.0$ & $11.8 \pm 1.2$ & 43 & 12.0 & $9.0-15.7$ & $12.0 \pm 1.6$ & 20 & 7.6 & $6.7-13.7$ & $10.6 \pm 2.2$ \\
\hline Mandibular ramus length & 20 & 14.8 & $10.2-15.0$ & $13.3 \pm 1.3$ & 43 & 13.4 & $11.0-15.4$ & $13.4 \pm 1.0$ & 20 & 15.0 & 12.8-19.6 & $15.2 \pm 1.7$ \\
\hline Maxillary barbel length & 20 & 7.0 & $5.8-9.1$ & $7.5 \pm 1.7$ & 43 & 10.2 & $5.5-14.1$ & $10.2 \pm 1.8$ & 20 & 7.6 & 7.6-18.8 & $11.0 \pm 3.0$ \\
\hline
\end{tabular}



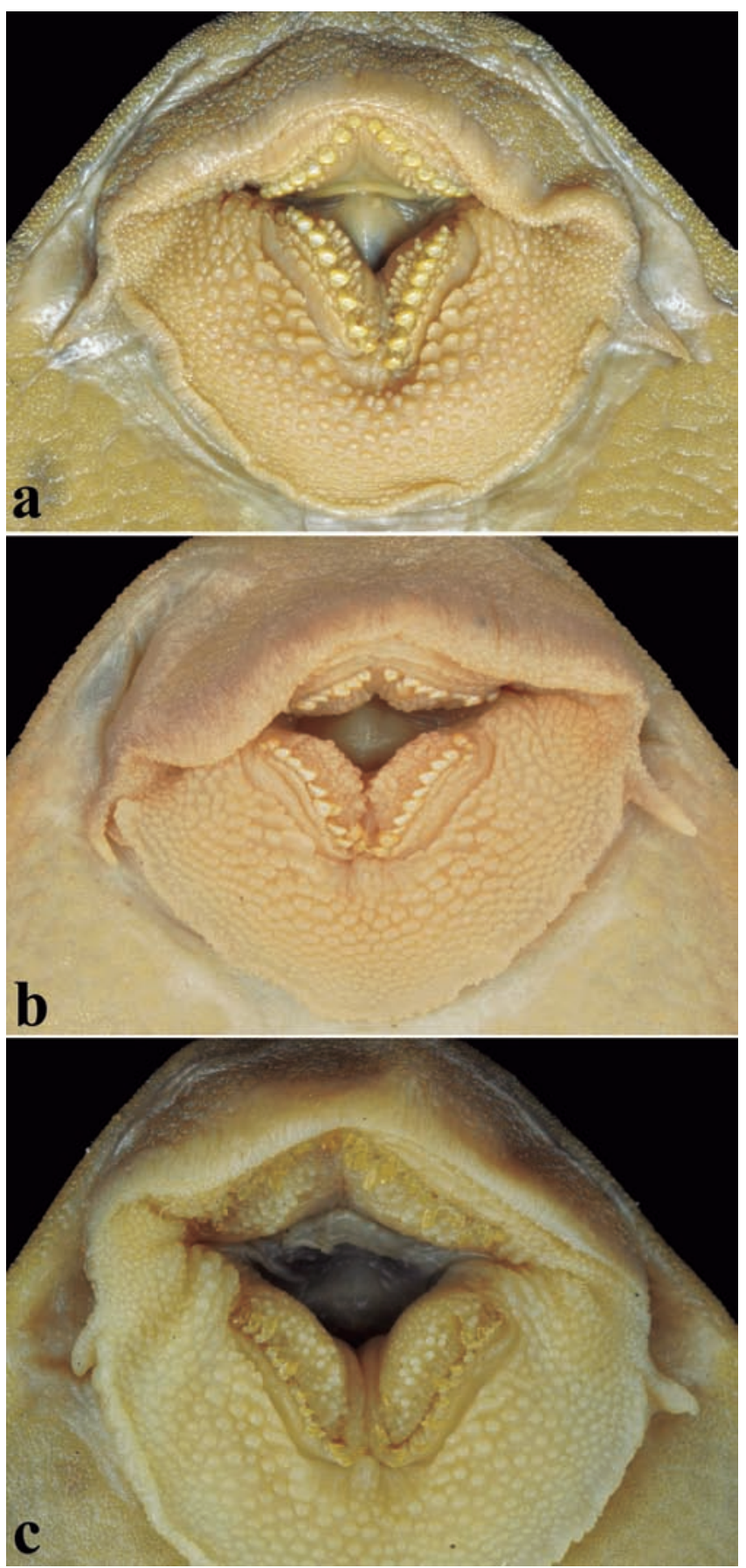

Fig. 5. Mouth and teeth of (a) Hypostomus cochliodon, NUP 10807, $208.0 \mathrm{~mm}$ SL, showing one series of papillae in inner face of upper and lower jaws; (b) Hypostomus basilisko, holotype, MZUSP 111110, $182.5 \mathrm{~mm}$ SL, showing the agglomerated papillae on inner face of upper and lower jaws; and (c) Hypostomus khimaera, MZUSP 111129, holotype, $139.1 \mathrm{~mm}$ SL, showing weakly developed papillae not forming series.

procurrent rays, then elevating again to caudal-fin insertion. Ventral profile almost straight from snout tip to insertion of pelvic-fin unbranched ray; slightly straight from pelvic-fin insertion to first ventral caudal-fin procurrent ray, then

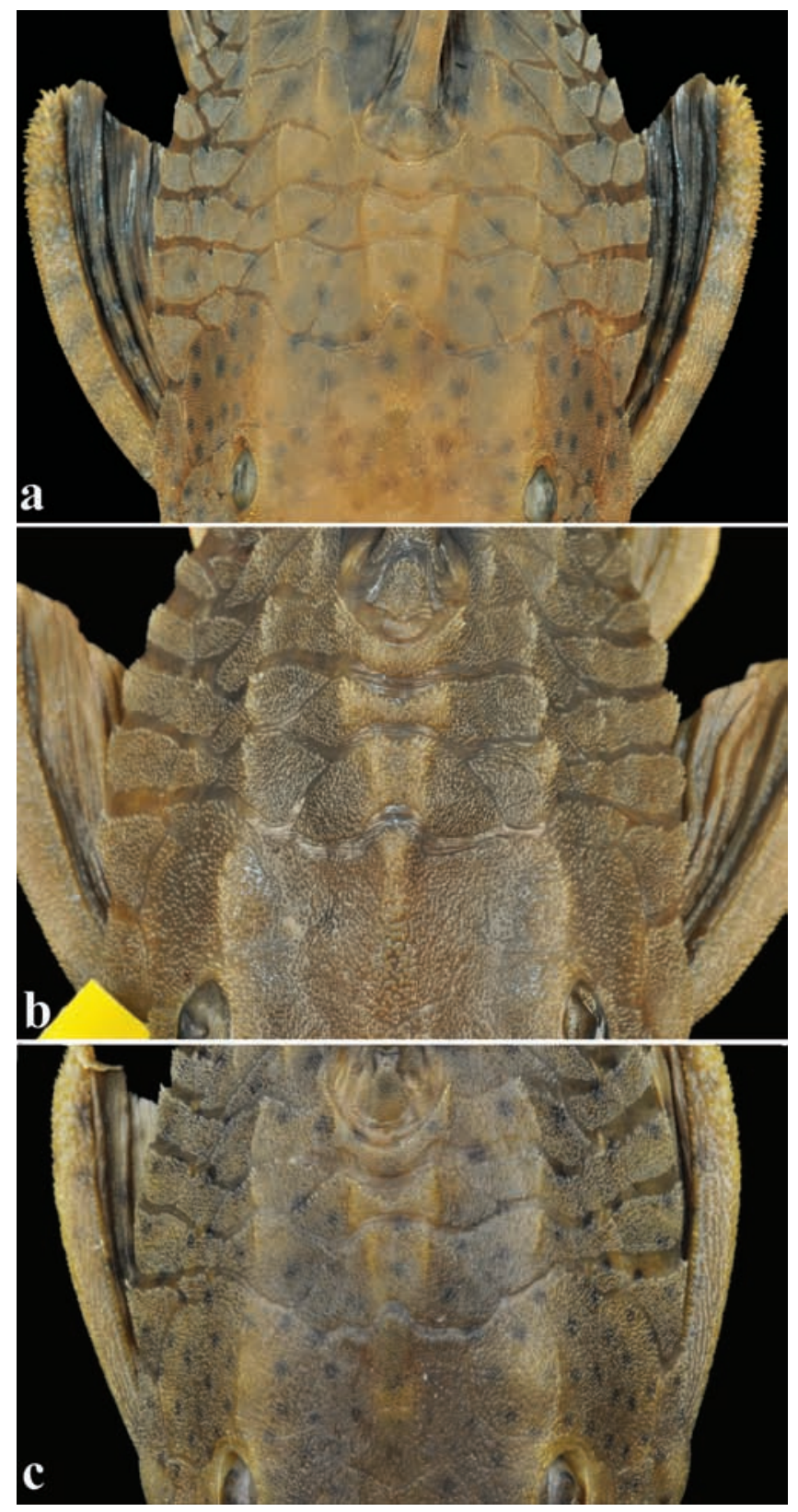

Fig. 6. Keels, ridges and odontodes of (a) Hypostomus cochliodon, NUP 10807, $208.0 \mathrm{~mm}$ SL, showing two weakly developed ridges in compound pterotic, weakly developed keels, few and weakly developed odontodes and predorsal keels weakly developed; (b) Hypostomus basilisko, holotype, MZUSP 111110, $182.5 \mathrm{~mm} \mathrm{SL}$, showing the three ridges on top of head, strongly developed keels, numerous welldeveloped odontodes on plates covering body and head and strong V-shaped predorsal keels; (c) Hypostomus khimaera, holotype, MZUSP 111129, 139.1 mm SL, showing moderately developed keels and dermal plates supporting moderately developed odontodes.

descending to caudal-fin insertion. Caudal peduncle laterally compressed, hexagonal on anterior region to very compressed on posterior region. Body dorsally covered with spinulose 
dermal plates, except on dorsal-fin base and small naked area on snout tip. Mesethmoid region densely covered by odontodes. Supraoccipital bone with highly developed median ridge; with short posterior process bordered by single plate. Conspicuous ridge originating laterally to nares, passing through supraorbital and extending through superior portion of compound pterotic. Exposed region of opercle large, ellipsoid and usually covered with several odontodes; odontodes more developed distally. Opercle completely surrounded by depression of thin skin layer (Fig. 3b). Oral disk round, moderate in size, lower lip not reaching vertical through gill openings (Fig. 5b); ventral surface covered with numerous small papillae decreasing in size posteriorly. Maxillary barbel slightly smaller than eye pupil. Odontodes present over anterior surface of upper lip, just anterior to snout. Buccal papilla (sensu Armbruster, 2003) absent. Dentaries acutely angled, averaging less than $80^{\circ}$ between left and right dentary rami. Ten to 13 teeth (mode $10^{*}$ ), ten to 13 teeth in dentary (mode 12, holotype 11). Bicuspid teeth with mesial cusp massive and round; spoon shaped; lateral cusp very reduced or fused to mesial cusp. Juveniles, up to $80 \mathrm{~mm}$ SL, with viliform bicuspid teeth, similar to those in general species of Hypostomus (see Armbruster, 2003, fig. 1c). Inner portion of anterior and posterior jaws supporting agglomerated well-developed papillae, usually more developed on inner posterior jaws (Fig. 5b).

Body dorsally covered with five rows of spinulose dermal plates, except on base of dorsal fin and small naked area on snout tip. Odontodes more developed on whole head surface; conical in shape. Predorsal region medially keeled; area between keels concave. These keels, which support hypertrophied odontodes, slightly diverge posteriorly (Fig. 6b). Dorsal and mid-dorsal series of plates with keels also supporting hypertrophied conical odontodes. Median series bearing lateral line and without keels; most plates support medially aligned slightly hypertrophied odontodes. Mid-ventral series highly angled to sixth or seventh plate, without keel posteriorly. Ventral series slightly bent ventrally on caudal peduncle. Ventral surface of head covered with platelets, except beneath lower lip. Abdomen covered with minute platelets in specimens larger than $80 \mathrm{~mm}$ SL, except for very small areas around pectoraland pelvic-fin insertions and at urogenital opening. Preanal plate present. Median series of plates with 27-28* (mode 28), three predorsal plates, plates between dorsal and adipose fins 7-8* (mode 8), plates between adipose and caudal fins 7-8* (mode 8) and plates below dorsal-fin base 7 .

Dorsal fin II,7, its origin at vertical through midpoint between pectoral and pelvic fins, or slightly posterior to that point. Dorsal-fin distal margin straight; dorsal-fin posterior rays not reaching adipose spine. Adipose-fin spine compressed and curved inward. Pectoral fin I,6, its distal border straight. Pectoral-fin spine slightly curved inward, covered with moderately developed odontodes, slightly more developed on its distal portion in larger specimens. Tip of adpressed pectoral fin reaching one-third of adpressed pelvicfin spine. Pelvic fin i,5, its distal border straight to slightly convex; its adpressed unbranched ray surpassing anal-fin

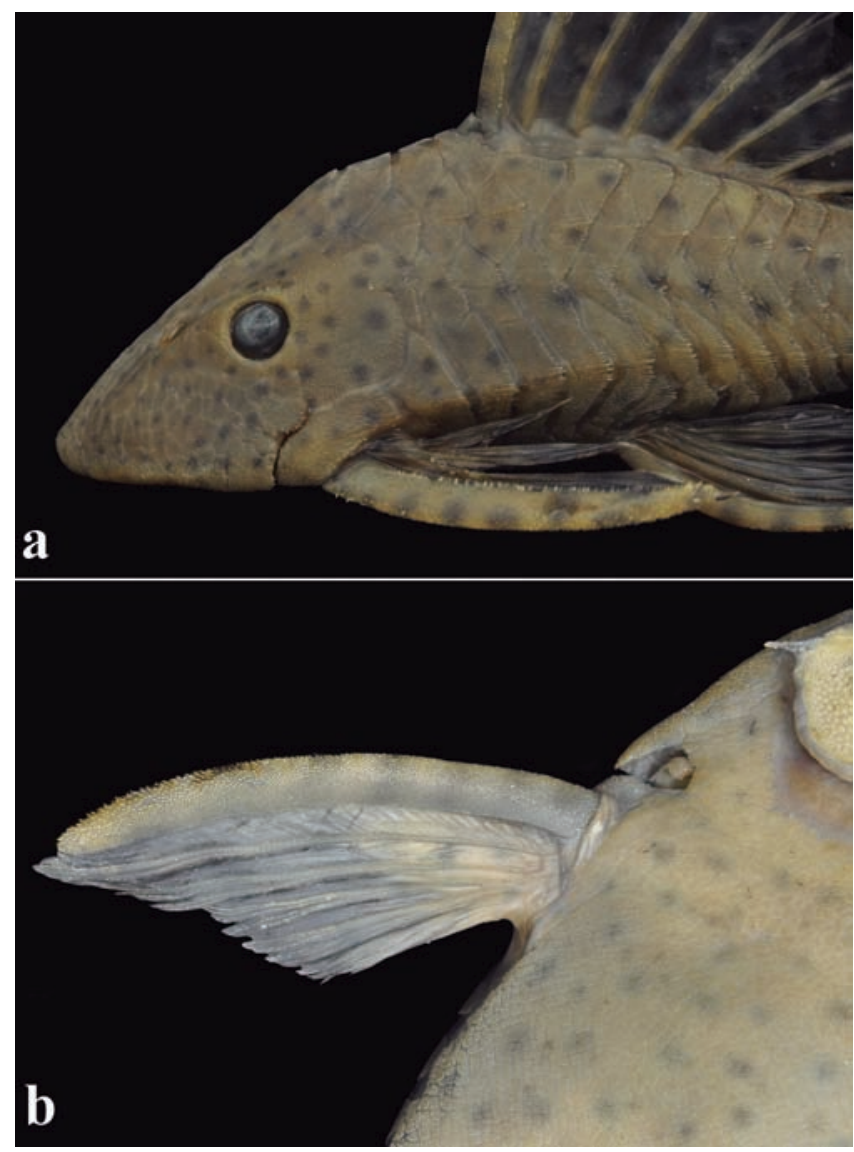

Fig. 7. Spots and color pattern of fins in Hypostomus cochliodon; (a) NUP 12071, $151.1 \mathrm{~mm}$ SL, showing spots smaller and closely spaced on head and larger and widely spaced on the body; (b) NUP 12768, $241.1 \mathrm{~mm}$ SL, the base of fin with same color of body, becoming dark brown in tip; and uniform spot pattern in ventral portion of body.

origin. Anal fin i,4, its tip reaching fifth to sixth plate after its origin. Rays of anal fin progressively increasing in size, third branched ray generally longer. Caudal-fin margin falcate, i,14,i, with ventral lobe slightly longer than dorsal one.

Color in alcohol. Ground color brown yellowish to brown reddish. Region between mid-dorsal and mid-ventral keels with faint tan stripe, more evident below dorsal-fin base. Fins lighter and slightly more reddish than trunk. Region around base of dorsal fin darker. Darker coloration around dorsal-fin base extends medially along dorsal portion of caudal peduncle, forming inconspicuous stripe on dorsal profile in some specimens. Spots on body, head or fins absent.

Color in life. Ground color of body reddish brown with faint tan stripe between mid-dorsal and mid-ventral keels in most specimens, with stripe more evident below dorsal-fin base (Fig. 11a); or yellowish brown overall in other specimens (Fig. 11b). Spots absent on trunk, head or fins. Fins lighter than trunk. Eye color golden with black pupil. 


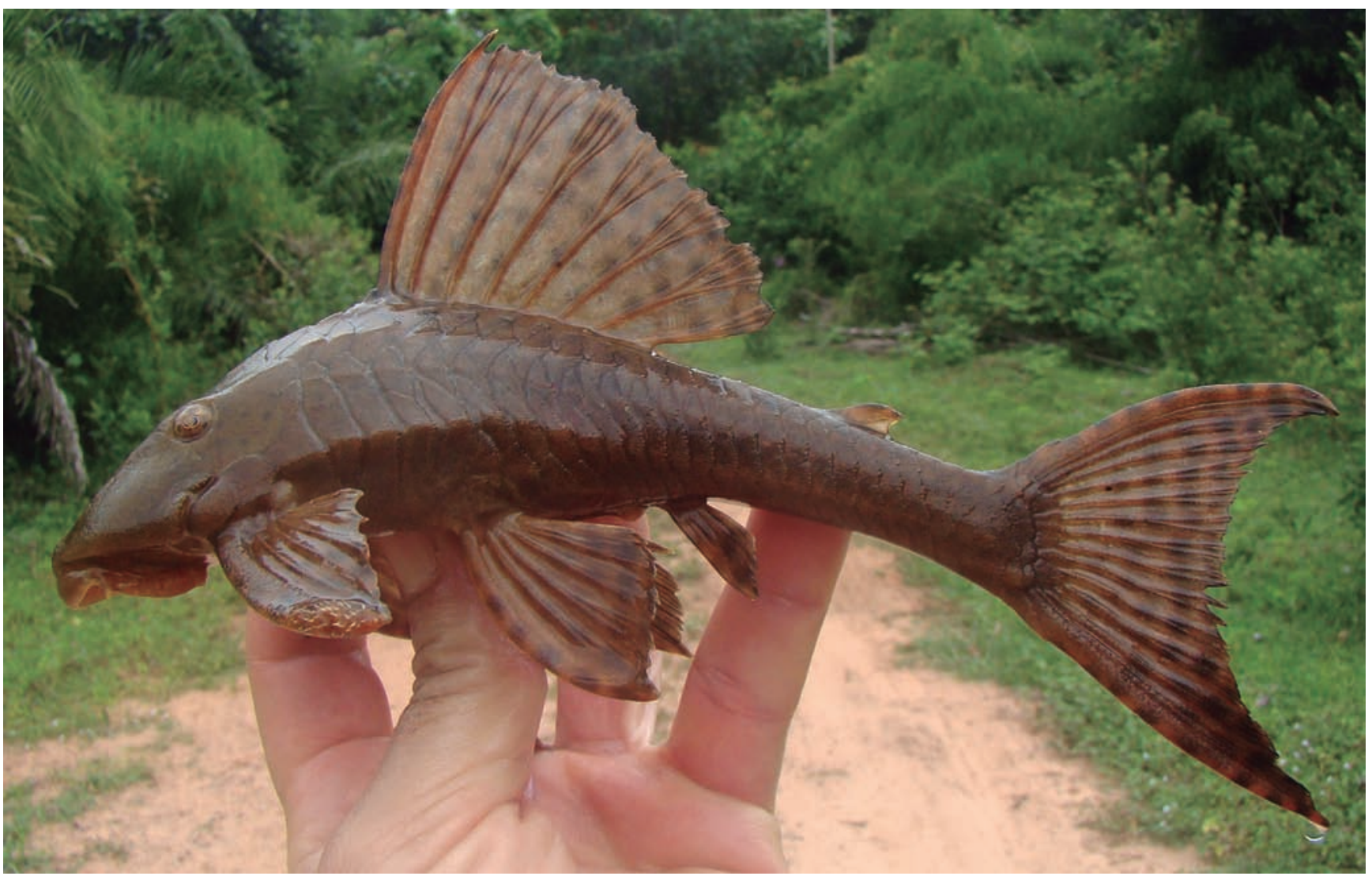

Fig. 8. Color pattern of live specimen of Hypostomus cochliodon (uncatalogued specimen) from córrego da Onça, Mato Grosso, rio Paraguay basin.

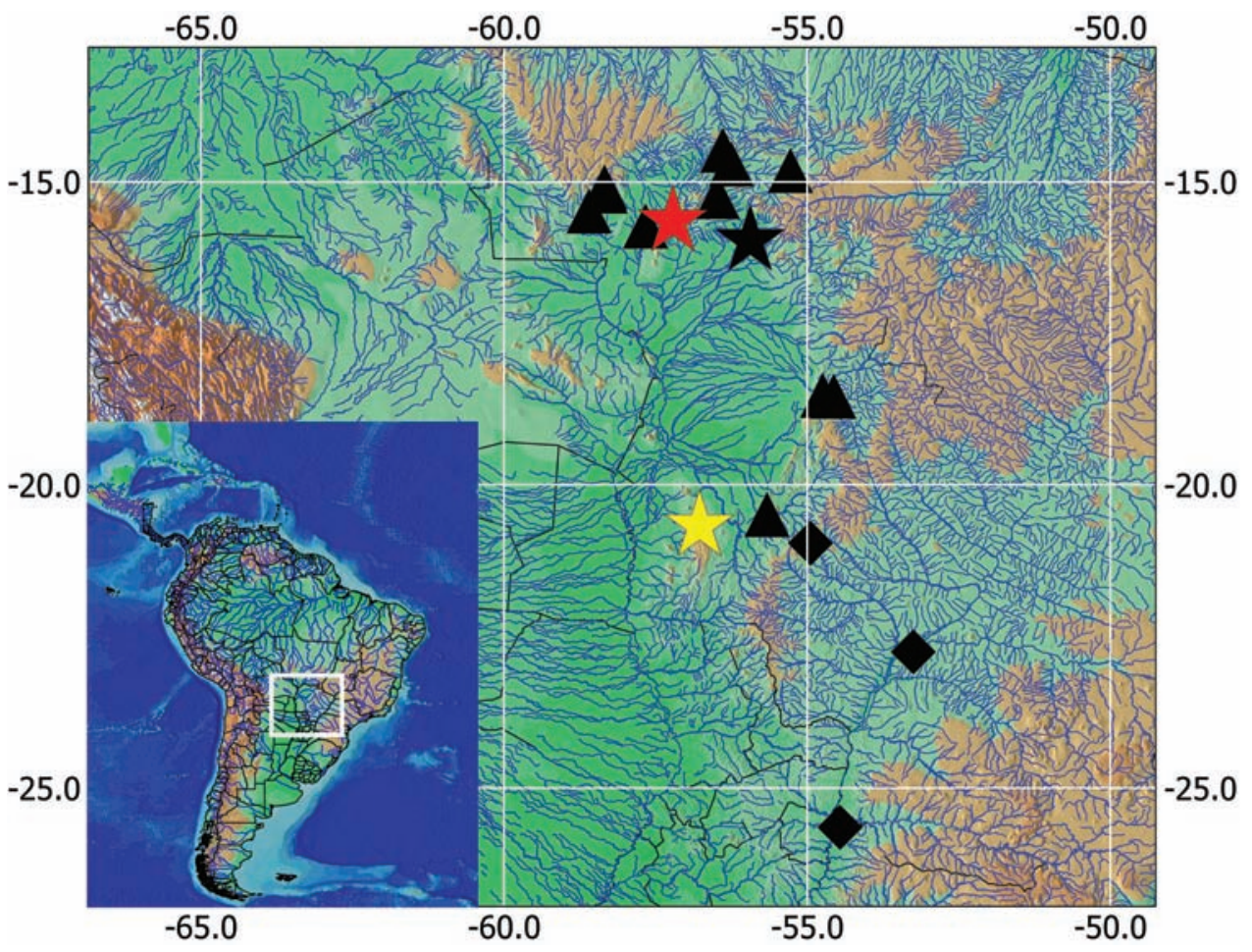

Fig. 9. Type locality of Hypostomus basilisko (yellow star), Hypostomus cochliodon (dark star) and Hypostomus khimaera (red star). The dark triangles represent areas of co-occurrence of Hypostomus cochliodon and Hypostomus khimaera; dark diamonds represent area of occurrence of Hypostomus cochliodon in the upper rio Paraná basin. 

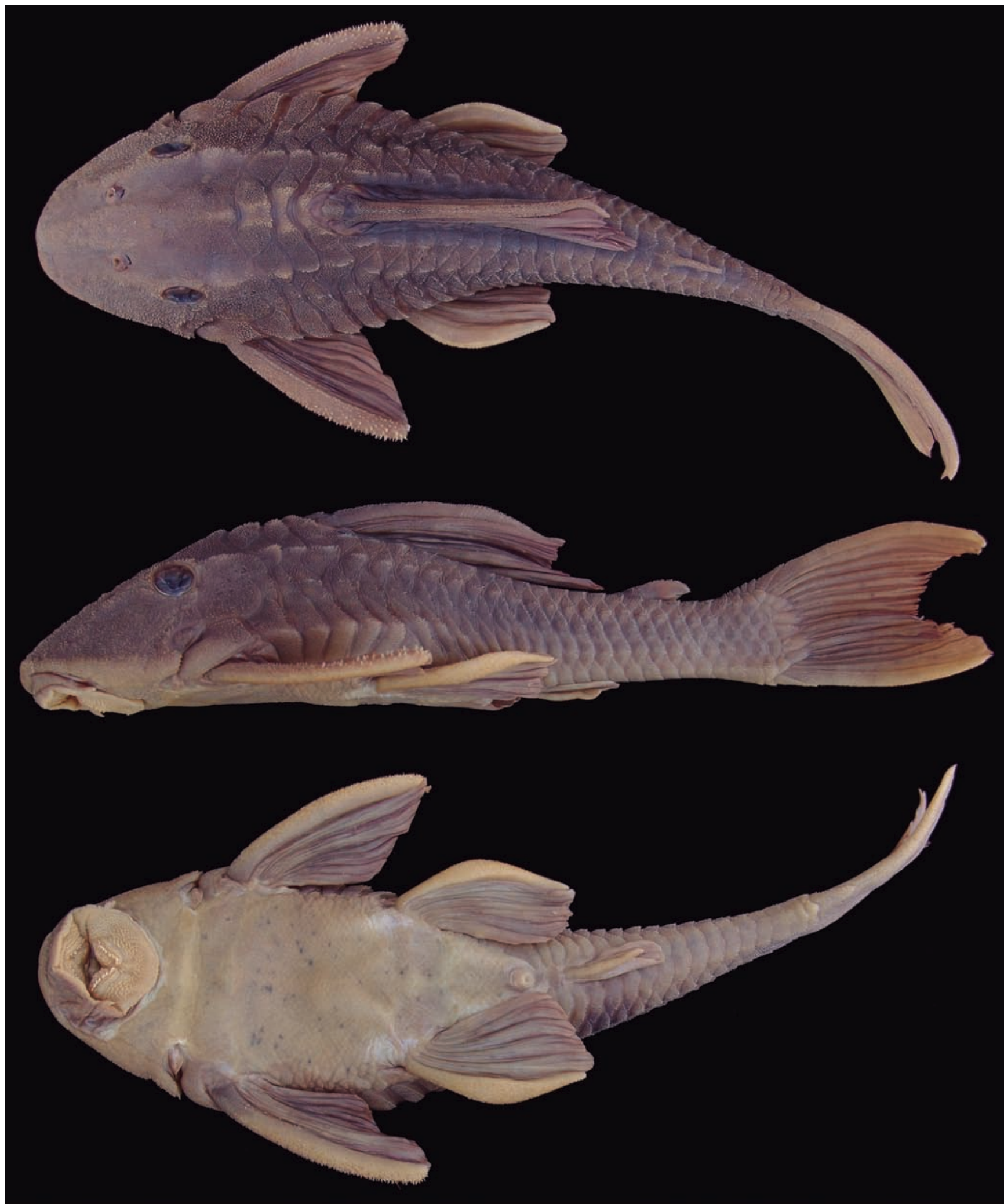

Fig. 10. Hypostomus basilisko, holotype, MZUSP 111110, 182.5 mm SL, córrego Salobrinha, rio Paraguay basin, Mato Grosso do Sul, Brazil; dorsal (top), lateral (middle), and ventral (bottom) views. 


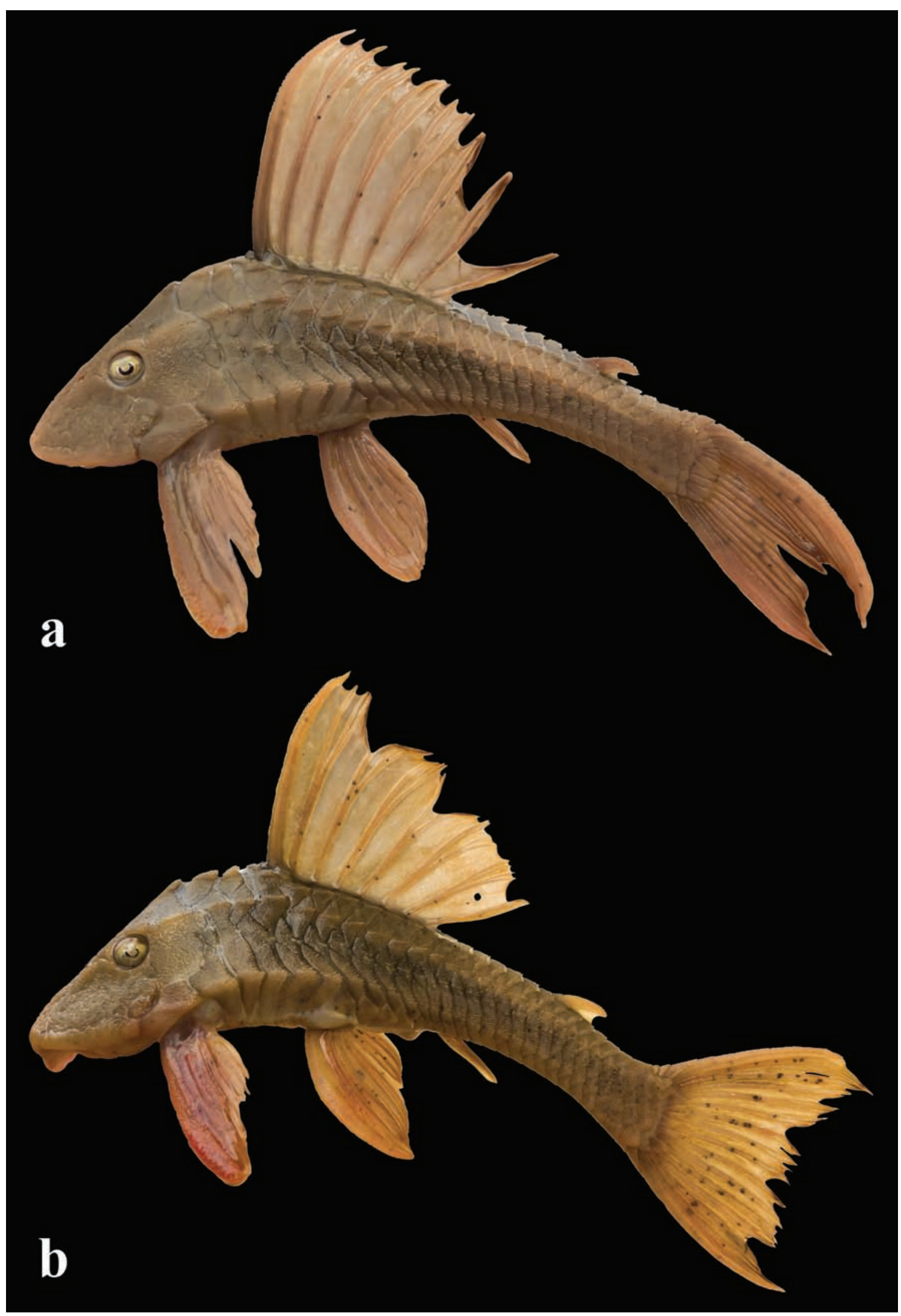

Fig. 11. Color pattern of live specimens of Hypostomus basilisko, paratypes (a) ZUFMS-PIS 3086, 150.5 mm SL, showing reddish-brown pattern; (b) ZUFMS-PIS 3086, 150.0 mm SL, showing yellowish-brown pattern. 

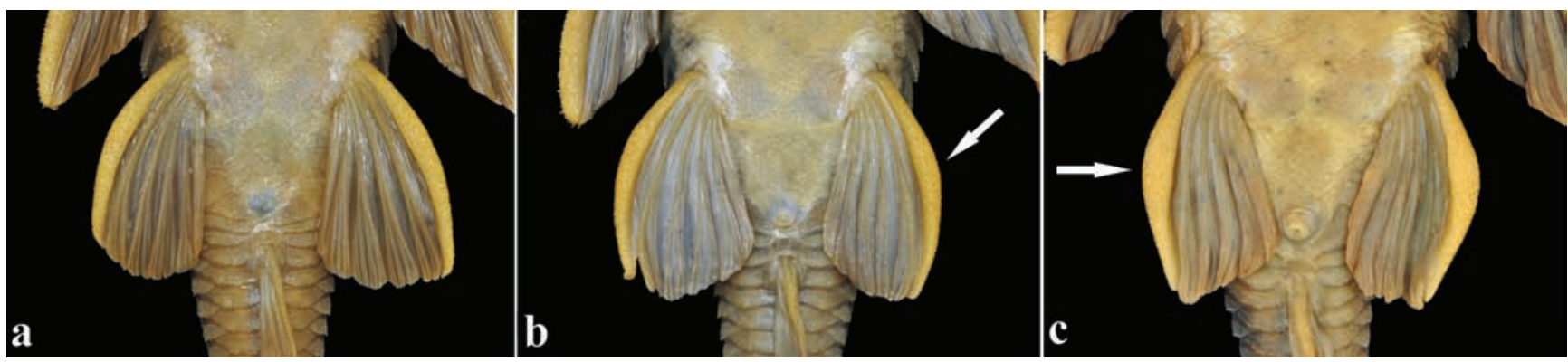

Fig. 12. Sexual dimorphism of Hypostomus basilisko; (a) MNRJ 40184, paratype, $162.3 \mathrm{~mm}$ SL, showing pelvic-fin spine with no tumescence in adult female; (b) MNRJ 40184, paratype, $149.1 \mathrm{~mm}$ SL, showing a weakly developed tumescence (indicated by arrow) in juvenile male; (c) MZUSP 111110, holotype, $182.5 \mathrm{~mm}$ SL, showing well-developed tumescence (indicated by arrow) in adult male.

Sexual dimorphism. Males with middle region of pelvic-fin spine thickened on ventral surface (Fig. 12).

Distribution. Hypostomus basilisko is known from rio Salobra basin of the rio Paraguay basin, Bodoquena Plateau, Mato Grosso do Sul, Brazil (Fig. 9).

Ecological notes. Hypostomus basilisko was collected and observed while snorkeling in clear-water streams and rivers of the Bodoquena Plateau. Larger individuals were easily observed during the day, lying on soft-bottom patches (mainly on sand, sometimes on leaf litter) at deeper sites. Those individuals foraged mainly during the night, when they sought shallower areas with rocky bottom. Occasionally, they were seen grazing during the day. Small individuals were observed foraging during the day and night, always in shallower areas.

Although, Hypostomus basilisko is part of a group of species that are usually reported as wood-eaters, individuals were observed foraging mainly on rocky substrates, as a periphyton grazer. Individuals also explored submerged logs and branches, but not to a noticeably greater extent than other species of Loricariidae that coexist with $H$. basilisko. The high degree of tooth abrasion that is usually observed in this species seems to support the idea that it does not use wood as its main food source.

Etymology. The Basilisk (from the Greek, basilisko $\varsigma$ [= basiliskos], diminutive of basileu [ [= basileus], meaning "little king") is a mythical creature known as the king of snakes, which is often represented with a crown on his head. This crown makes an allusion to the three strong ridges at the top of head of the new species. A noun in apposition.

Remarks. The most conspicuous characteristics used to recognize Hypostomus basilisko are its overall reddish brown color pattern that lacks spots, the rough and spiny body odontodes, and the conspicuous keels. Until now, the only species of the $H$. cochliodon group totally lacking spots is $H$. soniae and some specimens of $H$. pagei Armbruster. In fact, $H$. soniae is the most similar species to $H$. basilisko. However the new species is differentiated from $H$. soniae by having large spoon-shaped teeth, with the lateral cusp, when present, almost imperceptible versus bicuspid non spoon-shaped teeth, with mesial cusp larger than lateral cusp, but with the lateral one being clearly visible in $H$. basilisko. Another remarkable feature of $H$. basilisko is the presence of hypertrophied odontodes, which are conspicuous all over the body and even more remarkable on anterodorsal region of body in specimens up to $150.0 \mathrm{~mm} \mathrm{SL}$.

\section{Hypostomus khimaera, new species}

Figs. 3c, 4c, 5c, 6c, 13, 14

Hypostomus cochliodon Armbruster, 2003: 21 (partim; redescription).

Holotype. MZUSP 111129, 139.1 mm SL, Brazil, Mato Grosso State, Serra das Araras, Porto Estrela, córrego Salobo, rio Paraguay basin, 15³9’03"S 57²1’54"W, 2-3 Aug 1999, O. A. Shibatta.

Paratypes. CPUFMT 1449, 2, 112.2-126.9 mm SL; INPA 37744, 1, 125.5 mm SL; MNRJ 40185, 2, 105.5-128.1 mm SL; MZUEL 5821, 16, 37.5-113.2 mm SL; and NUP 14506, 4, 125.7-141.5 mm SL, collected with holotype.

Non-type material. 169 specimens. Brazil. rio Paraguay basin. Mato Grosso. LBP 5825, 1, 95.8 mm SL, Cuiabá, rio Coxipó. LBP 8496, 10, 47.5-104.5 mm SL, Porto Estrela, rio Salobra. MCP 15621, 1, 86.5 mm SL; and MCP 15785, 3, 85.4-113.0 mm SL, unnamed stream. MZUSP 44313, 4, 30.3-113.9 mm SL, Nova Olímpia, unnamed stream. MZUSP 78741, 5, 51.7-101.3 mm SL, Reserva do Cabaçal, ribeirão Sete de Setembro. MZUSP 78783, 7 of 8, 13.2-96.0 mm SL (13.2-96.0 mm SL), Indiavaí, rio Jaurú. MZUSP 78785, 4, 56.5-66.3 mm SL, Reserva do Cabaçal, rio Cabaçal. MZUSP 78853, 1, 156.7 mm SL, Diamantino, rio Paraguay. MZUSP 79135, 2, 69.688.8 mm SL, Cuiabá, rio Cuiabá. MZUSP 82036, 1, 109.0 mm SL, rio Sepotuba. MZUSP 90458, 1, 94.5 mm SL, rio Sepotuba. NUP 915, 12, 82.7-116.1 mm SL; and NUP 12393, 1, 146.6 mm SL, Chapada dos Guimarães, Manso Reservoir. NUP 2843, 2, 75.8-89.5 mm SL, Chapada dos Guimarães, rio Quilombo. NUP 3000, 2, 114.9-122.5 mm SL; and NUP 12014, 1, 27.2 mm SL, Santo Antônio do Leverger, rio Cuiabá. NUP 3037, 1, 89.2 mm SL, Chapada dos Guimarães, rio Casca. NUP 9723, 2, 61.8-72.4 mm SL, Cáceres, rio Piraputanga. 
NUP 11825, 1 c\&s, 69.5 mm SL, Cáceres, córrego Piraputanga. NUP 12005, 1, 139.0 mm SL; and NUP 12495, 1, 108.5 mm SL, Rosário Oeste, rio Manso. NUP 12006, 2, 91.8-107.1 mm SL, Barão de Melgaço, rio Cuiabá. NUP 12013, 1, 112.7 mm SL, Chapada dos Guimarães, rio Cuiabá. NUP 12015, 1, 95.9 mm SL, Barão de Melgaço, baia de Chacororé. NUP 12016, 1, 93.6 mm SL, Santo Antônio do Leverger. NUP 12121, 1, 91.4 mm SL, Nova Brasilândia, rio Manso.
NUP 13399, 4, 136.2-163.8 mm SL, Tangará da Serra, córrego Rico. NUP 13400, 1, 59.1 mm SL, Rondonópolis, córrego do Esparramo. NUP 13401, 1, 61.8 mm SL, Rondonópolis, córrego Pitaluga. NUP 13423, 3, 86.2-96.1 mm SL, Chapada dos Guimarães, rio Quilombo. NUP 13480, 11, 50.0-130.2 mm SL, Jangada, rio Jangada. Mato Grosso do Sul State. NUP 10982, 1, 99.1 mm SL; and NUP 11819, 3, 76.4-103.7 mm SL, Coxim, córrego da Onça. NUP 13269, 3, 64.1-

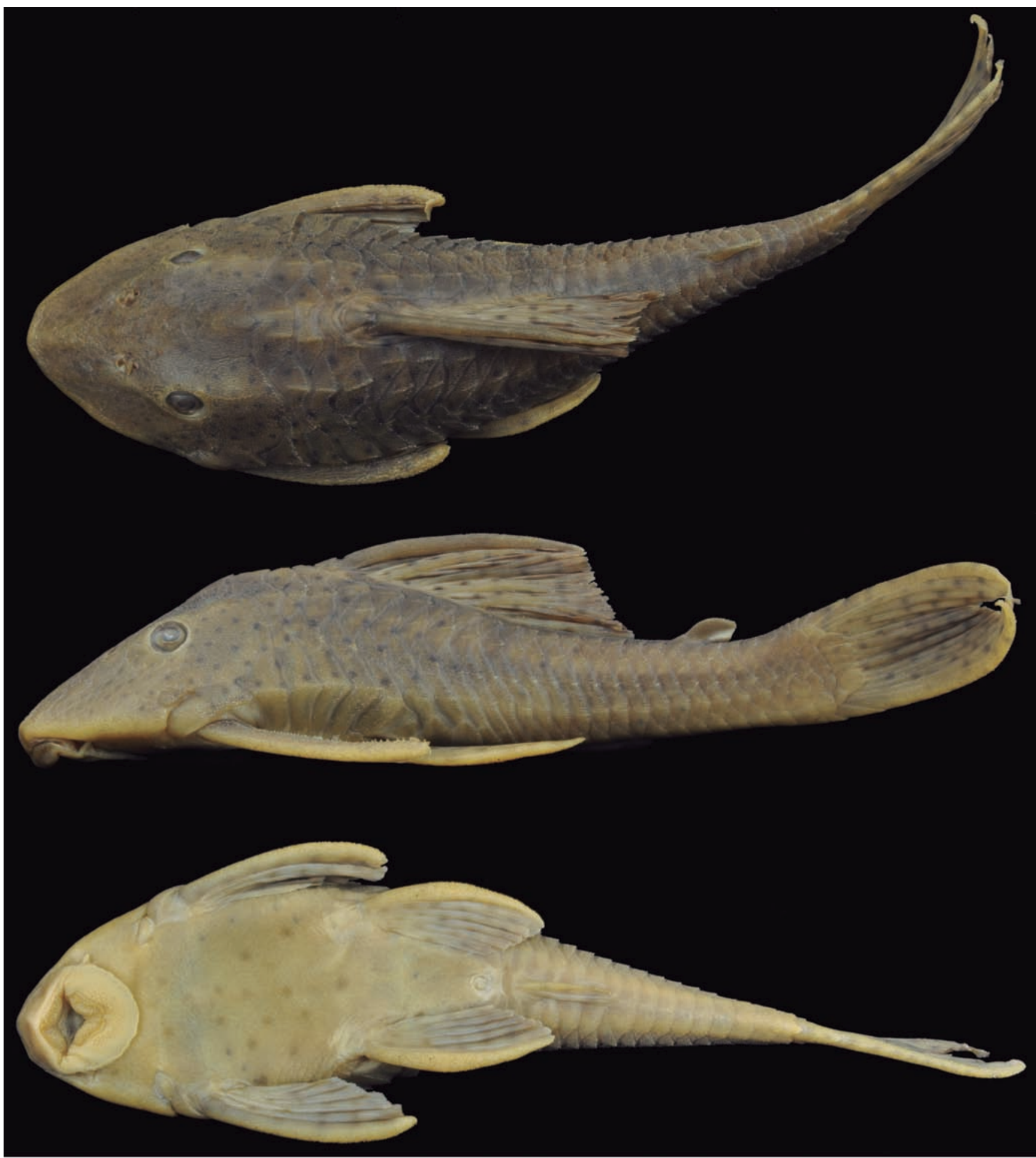

Fig. 13. Hypostomus khimaera, holotype, MZUSP 111129, $139.1 \mathrm{~mm}$ SL, from córrego Salobo, rio Paraguay basin, Mato Grosso State, Brazil; dorsal (top), lateral (middle), and ventral (bottom) views. 
81.5 mm SL, Rochedo, córrego Formiga. NUP 13270, 9, 43.4-93.0 mm SL, Rochedo, córrego Tamanduá. NUP 13494, 4, 61.2-73.1 mm SL, Terenos. ZUFMS-PIS 1316, 11, 27.5-71.0 mm SL, Aquidauana, córrego das Antas. ZUFMS-PIS 1978, 1, 115.7 mm SL, São Gabriel do Oeste, rio Coxim. ZUFMS-PIS 3539, 20, 39.0-73.0 mm SL, Jaraguari, córrego Furnas do Dionísio. ZUFMS-PIS 3557, 32, 26.0$77.0 \mathrm{~mm}$ SL, Corguinho, tributary to rio Aquidauana. ZUFMS-PIS 3738, 5, 8.8-10.6 mm SL, Terenos, rio Aquidauana.

Diagnosis. Hypostomus khimaera is distinguished from all other Hypostomus species, except those belonging to the $H$. cochliodon group, by having the following unique combination of features: notch between metapterygoid and hyomandibula absent (vs. notch present) and strongly angled dentaries, less than $80^{\circ}$ (vs. shallow angle between dentaries, generally more than $80^{\circ}$ ). Hypostomus khimaera can be distinguished from all other species of the $H$. cochliodon group, except from $H$. basilisko and $H$. soniae, by the presence of a dark tan stripe along the flank (vs. absence). The new species can be distinguished from $H$. basilisko and $H$. soniae by the presence of black spots on the body and fins or at least in one of these (vs. absence of spots). It can be additionally distinguished from $H$. basilisko in having moderately developed keels (vs. highly developed keels) and more vertebrae (28 vs. 27). The new species is additionally distinguished from $H$. cochliodon by having comparatively more teeth (12-27 vs. 7-9), externalized opercle, exposed region easily visible (Fig. 3b-c) (vs. almost entire internalized opercle, exposed region not easily visible (Fig. 3a) and fewer vertebrae (28 vs. 29).

Description. Morphometric data in Table 1. Overall view of body in Fig. 13, juvenile in Fig. 4c. Head broad, rough, moderately deep and slightly compressed. Snout and anterior profile of head pointed, sometimes slightly round, in dorsal view. Eyes moderate in size, laterally positioned. Dorsal margin of orbit slightly elevated. Compound pterotic covered by welldeveloped odontodes in some specimens. Greatest body width at cleithrum, then decreasing to caudal peduncle. Dorsal profile of head straight from snout tip to supraocciptal region, and forming angle of $45^{\circ}$ with ventral region of head; convex from that point to dorsal-fin origin; sloped downward to first dorsal caudal-fin procurrent rays, then elevating again to caudal-fin insertion. Ventral profile almost straight from snout tip to insertion of pelvic-fin unbranched ray; slightly straight from pelvic-fin insertion to first ventral caudal-fin procurrent rays, then descending to caudal-fin insertion. Caudal peduncle laterally compressed, broad on anterior region to very compressed on posterior region. Body dorsally covered with spinulose dermal plates, except of dorsal fin and small naked area on snout tip. Mesethmoid region covered by odontodes, more conspicuous anteriorly to nares. Moderate ridge originating laterally to nares, passing through supraorbital and extending through superior portion of compound pterotic. Exposed region of opercle ellipsoid and moderate in size; odontodes more developed distally. Opercle completely surrounded by thin layer of skin (Fig. 3c); covered by numerous odontodes. Oral disk round, relatively small in size, lower lip not reaching transversal through gill openings; ventral surface covered with numerous small papillae decreasing in size posteriorly (Fig. 5c). Maxillary barbel equal to or slightly larger than eye pupil. Odontodes present on anterior surface of upper lip, just anterior snout. Buccal papilla (sensu Armbruster, 2003) absent. Dentaries acutely angled, averaging less than $80^{\circ}$ between left and right dentary rami. Twelve to 27 teeth (mode 19 , holotype 21 ) in maxilla, twelve to 27 teeth (mode $22^{*}$ ) in dentary. Teeth shovel-shaped, bicuspid; mesial cusp round to oblong in ventral view and conspicuously more developed than lateral cusp; lateral cusp distinct and generally welldeveloped, sometimes fused to mesial cusp (similar to condition found in Hypostomus hemicochliodon, see Armbruster (2003, 2004) and H. soniae, see Hollanda Carvalho \& Weber, 2004). Juveniles with tooth morphology similar to adult specimens.

Body covered by five rows of rough and spiny dermal plates. Odontodes more concentrated on dorsal surface of head and medially on dermal plates. Dorsal-fin base naked. Predorsal region medially keeled; these keels moderate developed, slightly diverging posteriorly (Fig. 6c). Dorsal and mid-dorsal series of plates with moderate developed keels. Median series bearing lateral line and without keels. Mid-ventral series angled to fifth first plates, without keel posteriorly. Ventral series smooth angled ventrally towards posterior portion of caudal peduncle. Ventral surface of head covered with platelets, with exception to region beneath lower lip. Abdomen covered with minute platelets in specimens larger than $80 \mathrm{~mm} \mathrm{SL}$, with exception of very small areas around pectoral- and pelvic-fin insertions and at urogenital opening. Preanal plate present. Median series of plates with 26-28 (mode $27^{*}$ ), three predorsal plates, plates between dorsal and adipose fins $7 *_{-}-9$ (mode 7), plates between adipose and caudal fins $7{ }^{*}-8$ (mode 7 ) and plates below dorsalfin base $7 *-8$ (mode 7).

Dorsal fin II,7, its origin at vertical through midpoint between pectoral and pelvic fins or slightly posterior to that point. Dorsal-fin distal margin straight; dorsal-fin posterior rays not reaching adipose-fin spine. Adipose spine compressed and curved inward. Pectoral fin I,6, its distal border straight. Pectoral-fin spine slightly curved inward, covered with moderately developed odontodes, more developed on distal portion in larger specimens. Tip of adpressed pectoral fin reaching to one-third of adpressed pelvic-fin spine. Pelvic fin i,5, its distal border straight to slightly convex; its adpressed unbranched ray surpassing anal-fin origin. Anal fin i,4, its tip reaching sixth plate after its origin. Unbranched and fifth branched rays smaller than second, third, and fourth rays; third branched ray generally longest. Caudal fin i,14,i; distal margin falcate, with ventral lobe slightly longer than dorsal one.

Color in alcohol. Ground color generally yellowish-brown, some specimens tan. One faint stripe between mid-dorsal and midventral keels. Color of fins equal to ground color of trunk, sometimes lighter; some specimens with ventral lobe of caudal fin slightly darker than dorsal lobe. Region around dorsal-fin base darker, extending medially along dorsal portion of caudal peduncle, usually forming inconspicuous dark stripe on dorsal 


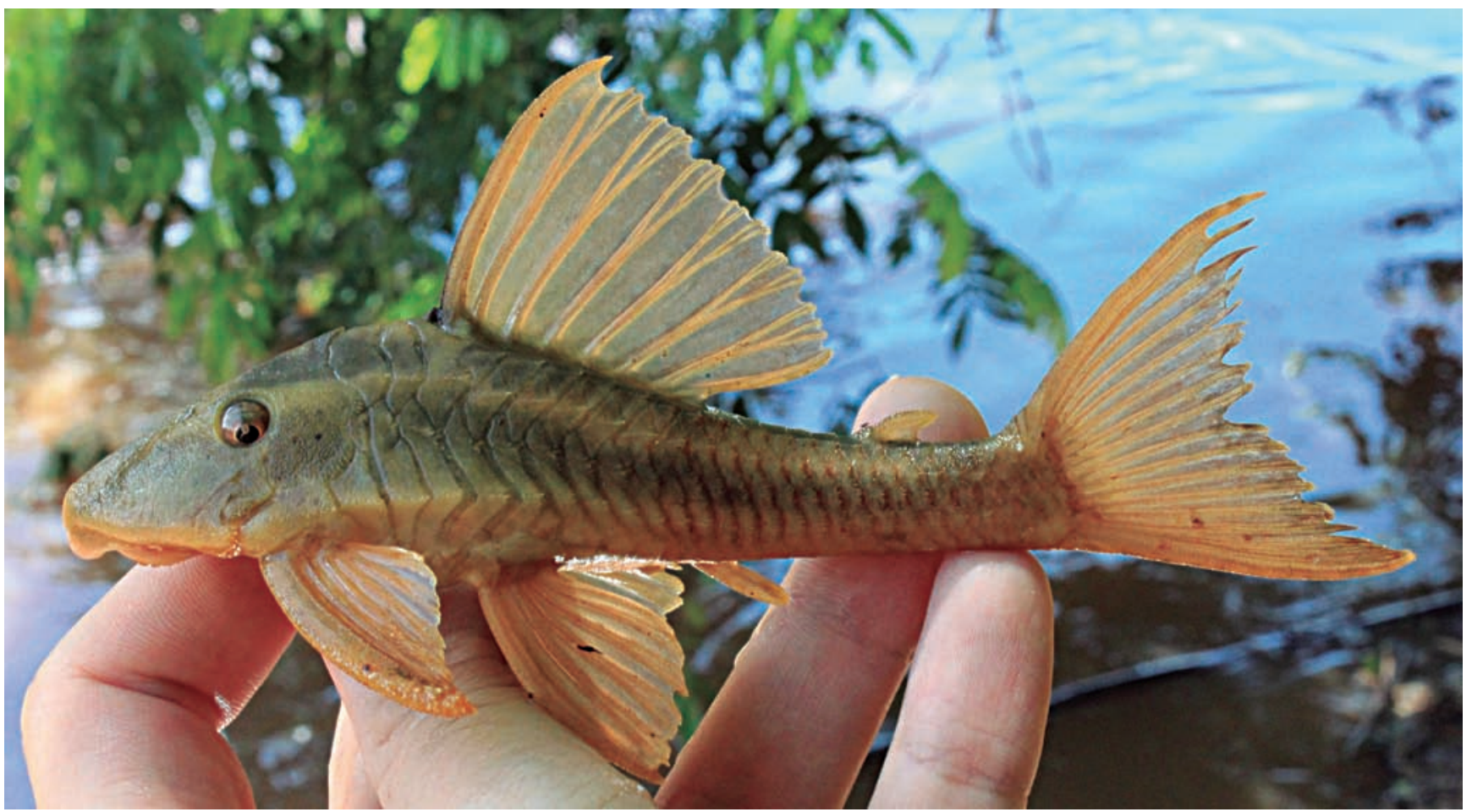

Fig. 14. Color pattern of live specimen of Hypostomus khimaera, ZUFMS-PIS 3738, 10.6 mm SL, rio Aquidauana, Mato Grosso do Sul, Brazil, showing the dark tan stripe along midline of flank and diffuse spots on the body.

region; anal fin color pattern similar to that of dorsal fin. Spots at least in some part of body and fins in all specimens. Body generally with sparse and small spots, concentrated on anterior portion of body; some specimens have few or even lack spots altogether. All fins generally covered by small spots, closely spaced; spots diffuse or absent in some specimens. Color pattern of juvenile specimens similar to adults; diffuse spots on body and fins in some juvenile specimens.

Color in life. Color in life is similar to that in alcohol preserved specimens, except for more visible stripes and more yellowishbrown ground color (Fig. 14).

Sexual dimorphism. No sexual dimorphism was observed.

Distribution. Hypostomus khimaera is known from several localities of rio Paraguay basin, such as rios Cuiabá, Manso, Quilombo, Coxipó, Coxim, baía de Chacororé, rios Vermelho and Aquidauana basins (Fig. 9).

Ecological notes. Hypostomus khimaera occurs syntopically with $H$. cochliodon in all aforementioned localities. However, in ichthyological surveys of headwater streams of rio Aquidauana basin, H. khimaera was more commonly found in small streams than in larger streams. In the rio Aquidauana basin streams, H. khimaera was collected generally along the margins of deeper sites with sandy bottoms.

Etymology. The epithet khimaera derives from the Greek, cimaira or khímaira, a mythological creature with hybrid body, formed essentially by three animals, a lion, a snake and a goat. The new species belongs to the Hypostomus cochliodon group, a group commonly associated with relatively few, spoon-shape teeth, but has, instead, numerous teeth that are not spoonshaped, very similar to that found in $H$. plecostomoides or $H$. soniae. However, its general body morphology is similar to $H$. cochliodon. The epithet khimaera makes an allusion due to the new species possess features of conspicuously distinct species. A noun in apposition.

Remarks. Some morphological differences were observed between the specimens from the rio Cuiabá and those from streams of rio Paraguay basin. Characters such as mesial cusp morphology (round to oblong), development of lateral cusp (moderate to well developed), development of keels (moderate to well developed) and roughness of the body plates (moderate to well developed odontodes on lateral body plates) usually show some degree of variation even among specimens collected at the same site. Due to the presence of such variations, only the specimens from the rio Salobo were designated as paratypes. However, some degree of morphological variation is more common among loricariid populations inhabiting small to medium rivers than in populations of species inhabiting channels of larger rivers (C. H. Zawadzki, pers. obs.). Probably, because the sedentary characteristics of most of the species of Hypostomus, any degree of geographical isolation can result in gradual levels of morphological variation from each small stream population to the neighboring ones. 


\section{Discussion}

Hollanda Carvalho \& Weber (2004) pointed out certain problems in the redescription of Hypostomus cochliodon made by Armbruster (2003), especially regarding the color pattern described by Armbruster, which differed from that described by Kner (1854), and also due to the large variation reported by Armbruster for some characters (e.g., number of teeth and color pattern). In the present work, some specimens from the rio Manso and rio Cuiabá (the type locality of $H$. cochliodon), exhibited a color pattern similar to that described by Armbruster (2003), while other specimens exhibit the color pattern described by Kner (1854) for $H$. cochliodon. Specimens that have the color pattern (with a dark brown stripe) which Armbruster (2003) described in his redescription of $H$. cochliodon can be clearly distinguished from those specimens showing the pattern described by Kner for $H$. cochliodon by the differences in the number and morphology of jaw teeth as well as the extent of development of keels along laterals of body and morphology of the opercle. Specimens with the dark brown stripe are named herein as $H$. khimaera and have been found in the type locality of $H$. cochliodon, and other nearby sites of the rio Paraguay basin. Therefore, Armbruster's redescription of $H$. cochliodon, appears to be a combination of these two species and that the "true" $H$. cochliodon has only a minimum of morphological and color variation through its whole geographical distribution.

Nuptial body odontodes were used by Armbruster (2003, fig. 4b) to diagnose his "odontodeless opercle group" (composed by Hypostomus cochliodon, $H$. ericius, $H$. levis, $H$. oculeus, $H$. pyrineusi, and $H$. taphorni), from the remaining species of the $H$. cochliodon group. Nuptial body odontodes sensu Armbruster (2003) are absent in $H$. cochliodon, $H$. basilisko, and $H$. khimaera. Even the well-developed odontodes of $H$. basilisko present conical shape (vs. triangular), which may signify that the "odontodeless opercle group” is not natural, since $H$. cochliodon (internalized opercle) and both new species (externalized opercle) present only conical-shaped odontodes on the body.

Armbruster (2003) stated that the variation in the number of opercular odontodes in Hypostomus cochliodon does not seem correlated with other morphological variations, and for this reason he maintained all his examined material as a single species (as mentioned by Hollanda Carvalho \& Weber, 2004). Despite the opercle of Hypostomus cochliodon generally does not support odontodes, while the two new species do, what really seems to determine the difference from $H$. cochliodon to $H$. basilisko and $H$. khimaera is not the number of odontodes supported by the opercle, but its own morphology. In $H$. cochliodon the opercle resembles that observed in $H$. ericius and $H$. pyrineusi (Fig. 3a; see also Armbruster, 2003), whereas in $H$. basilisko and $H$. khimaera, the opercle resembles that seen in $H$. plecostomoides and $H$. soniae (Fig. 3b-c; see also Armbruster, 2003).

In contrast, Hypostomus khimaera has numerous bicuspid teeth that are not spoon shaped, a dark stripe and exposed opercle bearing odontodes. Similar to what Armbruster (2004:
51) described for $H$. hemicochliodon, the teeth in $H$. khimaera also tends toward the spoon-shaped pattern found in most species of the $H$. cochliodon group. Despite the common association of the spoon-shaped teeth pattern with $H$. cochliodon species group, Armbruster (2003: 17) had already alluded to the presence of species without spoon-shaped teeth within this group by the time of his first revisionary study.

\section{Acknowledgments}

We are grateful to Oscar Shibatta for providing the typeseries specimens of Hypostomus khimaera. To Weferson da Graça for the inestimable conversations about fish taxonomy and suggestions on the manuscript. To anonymous reviewers by solid contributions and valuable suggestions during the review process. To Pedro Hollanda Carvalho for sharing his knowledge about the Hypostomus cochliodon group with the authors. To Bárbara Calegari and Pedro Hollanda Carvalho for sending photographs of specimens of $H$. cochliodon and $H$. khimaera. To Angela Ludwig and Brian Wilson for helping with the English language. We also thank Bruno dos Santos, Edson Okada, Francisco Neto, Jayson Farias, João Latini, Roberto dos Santos, Samuel Veríssimo, and Vladimir Domingues for help in fieldwork. Thanks are also due to Mark Sabaj Perez and John Lundberg (ANSP), Barbara Brown and Scott Schaefer (AMNH), Patrick Campbell (BMNH), David Catania, William Eschmeyer and Tomio Iwamoto (CAS), Kevin Swagel and Mary Anne Rogers (FMNH), Claudio Oliveira, Fábio Roxo and Ricardo Britzke (LBP), Paulo Buckup and Marcelo Britto (MNRJ), Margarete Lucena and Roberto Reis (MCP), Oscar Shibatta (MZUEL), José Lima Figueiredo and Osvaldo Oyakawa (MZUSP), Helmut Wellendorf (NMW) for loan of comparative material and hosting museum visits. Nupélia and MZUSP provide us with logistical support. The Coordenação de Aperfeiçoamento de Pessoal de Nível Superior (CAPES) provided fellowships to LFCT. Visit to museum collections by CHZ were funded by the All Catfish Species Inventory (DEB-0315963). CHZ was funded by the Conselho Nacional de Desenvolvimento Científico e Tecnológico (CNPq - 310733/2013-8).

Comparative material. Hypostomus dardanelos. Brazil. INPA 37342, 1, 172.2 mm SL, holotype, rio Praia Grande (at its mouth to rio Aripuanã downstream cachoeira Dardanelos and Andorinhas). Hypostomus ericae. Brazil. MHNG 2650.026, 1, 130.5 mm SL, paratype, rio Maranhão. MNRJ 27861, 1, 164.3 mm SL, holotype, rio Tocantins. NUP 6436, 1, 155.4 mm SL, córrego Fundo. NUP 8298, 1, 53.0 mm SL, unname stream. Hypostomus ericius. Peru. AMNH 218035, 1, 85.3 mm SL, paratype, upper río Amazon. ANSP 176149, 1, 104.0 mm SL, paratype, río Nanay. MUSM 27553, 1 of 4, 110.0 mm SL, río Breu. Hypostomus fonchii. Peru. MHNG 2613.066, 1, 141.0 mm SL, holotype, río Cushabatay basin. Hypostomus hemicochliodon. Ecuador. FMNH 106021, 2, 31.0-106.0 mm SL, rio Payamino. FMNH 106024, 1, 159.0 mm SL, rio Payamino. Venezuela. ANSP 185320, $228.0 \mathrm{~mm}$ SL, Crano Grula, tributary to río Orinoco. Hypostomus hondae. Colombia. AMNH 12599, 1, 124.0 mm SL, río Macauá. BMNH 1909.7.23.44, 1, 59.1 mm SL, 
paratype. SU 50373, 1, 106.0 mm SL, rio Samana, rio Magadalena basin. SU 56863. Venezuela. CAS 136504, 2, 50.0 and 59.7 mm SL, río Monay. Hypostomus kopeyaka. Brazil. MZUSP 98764, 1, 226.1 mm SL, holotype, rio Tiquié. NUP 8019, 1, 140.4 mm SL, igarapé Castanha, tributary of rio Tiquié. Hypostomus levis. Bolivia. UMSS 1721, 187.9 mm SL, río Paraguá. Hypostomus oculeus. Colombia. FMNH 106015, 1, 130.0 mm SL, río Aguarico. FMNH 106016, 3, 52.0-183.0 mm SL, río Payamino. Hypostomus pagei. Suriname. ZMA 109.982, 1, 189.2 mm SL, Whilhelmina mountains. Hypostomus paucipunctatus. Brazil. MHNG 2652.017, 2, 135.6-155.0 mm SL, paratypes, rio Itacaiúnas. MZUSP 82271, 1, 177.1 mm SL, holotype, rio Itacaiúnas. Hypostomus plecostomoides. Brazil. ZMA 120.168, 1, 133.4 mm SL, rio Tapajós. Venezuela. ANSP 166889, 1, 215.0 mm SL, río Orinoco. ANSP 180718, 2, 38.6-175.0 mm SL, río Inambari. CAS 12694, 1, 214.0 mm SL, río Bue. Hypostomus pyrineusi. Bolivia. ZSM 22025, 2, 241.6-241.7 mm SL, río Chipiriri. Brazil. MNRJ 863, 1, 204.0 mm SL, holotype, probably rio Jamari. MNRJ 31899, 1, 176,7 mm SL, rio Urupá, rio Machado basin. NUP 10047, 1, 150.3 mm SL, rio Jaciparaná, rio Madeira basin. NUP 10984, 2, 168.9169.9 mm SL, ribeirão Xambioazinho, rio Tocantins-Araguaia basin. Peru. FMNH 97017, 3, 76.0-132.0 mm SL, rio Marañon. FMNH 113911, 1, 126.0 mm SL, Loreto. Hypostomus macushi. Venezuela. AUM 35510, 1, 148.1 mm SL. AUM 45064, 1, 170.0 mm SL. Hypostomus simios. Brazil. MHNG 2652.018, 1, 112.0 mm SL, paratype, rio Cupixi. MZUSP 82268, 1, 157.9 mm SL, holotype, rio Cupixi. Hypostomus sculpodon. Venezuela. AUM 39476, 1 of 2, 220 mm SL. AUM 40220, 1, 229 mm SL. AUM 42188, 4 of 7, 219264 mm SL. Hypostomus soniae. Brazil. MHNG 2547.012, 13, 35.4-143.0 mm SL, paratypes, rio Tapajós. MNRJ 35619, 10 of 38, 97.4-163.7 mm SL, rio Cristalino, rio Tapajós basin. NUP 13394. 1, 143.3 mm SL, córrego do Valdir, tributary to rio Teles Pires. Hypostomus taphorni. Venezuela. AMNH 13664, 1, 189.0 mm SL, Essequibo River. Hypostomus waiampi. Brazil. MHNG 2652.016, 1, 174.4 mm SL, paratype, rio Cupixi. Hypostomus weberi. Brazil. MZUSP 98767, 1, 149.3 mm SL, holotype, rio Negro. NUP 6344, 1, 156.6 mm SL, paratype, rio Marauiá.

\section{Literature Cited}

Armbruster, J. W. 2003. The species of the Hypostomus cochliodon group (Siluriformes: Loricariidae). Zootaxa, 249: 1-60.

Armbruster, J. W. 2004. Phylogenetic relationships of the suckermouth armored catfishes (Loricariidae) with emphasis on the Hypostominae and the Ancistrinae. Zoological Journal of the Linnean Society, 141: 1-80.

Armbruster, J. W. \& L. de Souza. 2005. Hypostomus macushi, a new species of the Hypostomus cochliodon group (Siluriformes: Loricariidae) from Guyana. Zootaxa, 920: 1-12.

Boeseman, M. 1968. The genus Hypostomus Lacépède, 1803, and its Surinam representatives (Siluriformes: Loricariidae). Zoologische Verhandelingen, 99: 1-89.

Graça, W. J. \& C. S. Pavanelli. 2007. Peixes da planície de inundação do alto rio Paraná e áreas adjacentes. Maringá, Eduem.

Hollanda Carvalho, P. \& C. Weber. 2004. Five new species of the Hypostomus cochliodon group (Siluriformes: Loricariidae) from middle and lower Amazon System. Revue suisse de Zoologie, 111: 953-978.
Hollanda Carvalho, P., F. C. T. Lima \& C. H. Zawadzki. 2010. Two new species of the Hypostomus cochliodon group (Siluriformes: Loricariidae) from the rio Negro basin in Brazil. Neotropical Ichthyology, 8: 39-48.

International Commission on Zoological Nomenclature. 2003. Declaration 44. Amendment of Article 74.7.3. Bulletin of Zoological Nomenclature, 60: 263.

Kner, R. 1854. Die Hypostomiden. Zweite Hauptgruppe der Familie der Panzerfische. (Loricata vel Goniodontes). Denkschriften der Mathematisch- Naturwissenschaftlichen Classe der Kaiserlichen Akademie der Wissenschaften in Wien, 7: 251-286.

Montoya-Burgos, J. I., C. Weber \& P. -Y. Le Bail. 2002. Phylogenetic relationships within Hypostomus (Siluriformes: Loricariidae) and related genera based on mitochondrial D-loop sequences. Revue suisse de Zoologie, 109: 369-382.

Nelson, J. A., M. E. Whitmer, E. A. Johnson, D. Wubah \& D. J. Stewart. 1999. Wood-eating catfishes of the genus Panaque Eigenmann \& Eigenmann, 1889: gut microflora and enzyme activities. Journal of Fish Biology, 54: 1069-1082.

Oyakawa, O. T., A. Akama \& A. M. Zanata. 2005. Review of the genus Hypostomus Lacépède, 1803 from rio Ribeira de Iguape basin, with description of a new species (Pisces, Siluriformes, Loricariidae), Zootaxa, 921: 1-27.

Schaefer, S. A. 1997. The Neotropical cascudinhos: systematics and biogeography of the Otocinclus catfishes (Siluriformes: Loricariidae). Proceedings of the Academy of Natural Sciences of Philadelphia, 148: 1-120.

Schaefer, S. A. \& D. J. Stewart. 1993. Systematics of the Panaque dentex species group (Siluriformes: Loricariidae), wood-eating armored catfishes from tropical South America. Ichthyological Exploration of Freshwaters, 4: 309-342.

Taylor, W. R. \& G. C. Van Dyke. 1985. Revised procedures for staining and clearing small fishes and other vertebrates for bone and cartilage study. Cybium, 9: 107-119.

Weber, C. 1985. Hypostomus dlouhyi, nouvelle espèce de poisson chat cuirassé du Paraguay (Pisces, Siluriformes, Loricariidae). Revue suisse de Zoologie, 92: 955-968.

Weber, C. 2003. Subfamily Hypostominae (Armored catfishes). Pp. 351-372. In: Reis, R. E., S. O. Kullander \& C. J. Ferraris (Eds.). Check List of the Freshwater Fishes of South and Central America. Porto Alegre, Edipucrs.

Weber, C. \& J. I. Montoya-Burgos. 2002. Hypostomus fonchii sp. n. (Siluriformes: Loricariidae) from Peru, a key species suggesting the synonymy of Cochliodon with Hypostomus. Revue suisse de Zoologie, 109: 355-368.

Zawadzki, C. H., E. Renesto, R. E. Reis, M. O. Moura \& R. P. Mateus. 2005. Allozyme relationships in hypostomines (Teleostei: Loricariidae) from the Itaipu Reservoir, Upper Rio Paraná basin, Brazil. Genetica, 123: 271-283.

Zawadzki, C. H., C. Weber \& C. S. Pavanelli. 2008. Two new species of Hypostomus Lacépède (Teleostei: Loricariidae) from the upper rio Paraná basin, Central Brazil. Neotropical Ichthyology, 6: 403412.

Submitted September 4, 2012 Accepted February 20, 2014, by Paulo H. F. Lucinda Published September 30, 2014 